\title{
Interregional Inventor Mobility in the Russian Federation as Evidenced by European Patent Data
}

\author{
Jens K. Perret ${ }^{1}[$ \\ Received: 24 April 2018 / Accepted: 30 June 2021/Published online: 19 July 2021 \\ (C) The Author(s) 2021
}

\begin{abstract}
The transmission of knowledge between different entities is a central part of the concept of the national innovation system introduced by Lundvall. As knowledge in general, and tacit knowledge specifically, is a statistically rather intangible concept, alternative concepts need to be implemented to account for it. This study uses the idea of inventor mobility to account for tacit knowledge transmissions across the regions of the Russian Federation. In particular, the combination of the results of both ideas is used to account for purely inventor-based knowledge flows. These flows are quantified, and it is shown that basic economic indicators like the quality of the regional research system and the regional income levels are suitable in describing the intensity of knowledge flows.
\end{abstract}

Keywords Inventor mobility · Patent data $\cdot$ Russian Federation · Tacit knowledge · Spatial econometrics

JEL Classification $\mathrm{O} 31 \cdot \mathrm{P} 25 \cdot \mathrm{R} 15$

\section{Introduction}

In 1992 Lundvall introduced the concept of the national innovation system (NIS) into economic literature providing a comprehensive frame of reference to analyze the innovation dynamics in economies. Following the OECD's 1999 report on national innovation systems, regional innovation systems are the essential building blocks of any NIS. The analysis of an NIS.The analysis of an NIS is therefore inherently of a regional nature.

At the core of every NIS two concepts is of central importance: The generation and the diffusion of innovations and ergo knowledge; on the one hand inside the system itself and on the other across the system's borders.

\section{Jens K. Perret}

jens.perret@ism.de

1 International School of Management, Im MediaPark 5c, 50670 Cologne, Germany 
The present study picks up on the aspect of knowledge diffusion and tries to quantify it in the context of the Russian Federation (RF) ${ }^{1}$. The RF experienced over the last two decades a transition from a Soviet centrally planned economy to a market economy; however, it is still not considered to be a fully developed knowledge society comparable to Western European economies where the terms of knowledge society or knowledge economy can be interchanged with the term NIS.

In this context the Russian Federation is a very interesting subject not only because it has a much different history and recent development path than most established knowledge societies but also because it is politically as well as economically in a phase which many developed nations have long since left behind. An analysis of the RF therefore allows us to take a look at how an innovation system-or at least the knowledge transmission mechanism - in such a developing economy under such specific restrictions looks and works. It can thus be taken as an analytical template for other BRICS countries or countries at a similar level of development and comparable economic characteristics like Indonesia.

This study furthermore aims at uncovering in how far the RF reports patterns of an NIS comparable to Western European standards by analyzing inventor mobility networks across the regions of the $\mathrm{RF}^{2}$. This approach considers one aspect of the transfer of tacit knowledge across regional borders, however, flawed the approach by itself or the data source might be.

Aside from inventor mobility networks, different approaches could be used to study the knowledge diffusion mechanism in a NIS. The significant advantage of the first, however, lies in the fact that flows of tacit knowledge are observed as compared to flows of codified knowledge as is the case for example with patent citations. The advantage of studying tacit knowledge flows is that a significant share of knowledge if not all $^{3}$ is tacit and cannot be codified but remains bound to its human carriers. In this context the present study complements the study of (Perret, 2015) where codified knowledge flows have been analyzed. An advantage of using inventor mobility networks as compared to star researcher networks, an alternative tool to measure tacit knowledge flows, is that the units of observation are defined via the methodology and do not have to be specified beforehand. In this context inventor mobility networks - in particular the one in this study_consider the whole population and not just a sub-sample thereof. While the study of firm relocation offers an additional alternative to inventor movements, it follows the debate on incentives for foreign direct investments and an additional quantitative analysis could only add so much to the debate as inter-regional firm locations are only in part different from international firm location.

Through quantification of the inventor mobility networks into panel data, it becomes possible to identify factors that have a significant influence on the different

\footnotetext{
1 A first comprehensive analysis of the knowledge generation and transmission process in the RF can be found in (Perret, 2013), later specified in (Perret, 2015) and (Perret, 2017).

${ }^{2}$ We talk about inventor mobility when an inventor supposedly moved from one region to another. Whereby such a move is measured via patents.

3 See (Leonard \& Sensiper, 1998).
} 
types of inventor/knowledge flows-inventor flows can be divided into inventor inflows and inventor outflows. In its proceedings and the applied methodology, the analysis in this study is strongly influenced by the studies of (Scherngell et al., 2007), (Miguélez et al., 2010), (Barber \& Scherngell, 2011), (Emons, 2012) and (Welfens, 2012) among others.

The study is structured in six sections. In the following second section a structured review of key publications on the topic of inventor mobility is given underlining the need for an RF-oriented analysis of interregional inventor flows. The implemented methodology is introduced in the third section as well as related aspects taken from graph theory and social network analysis that are needed to generate and interpret networks of codified and tacit knowledge flows.

The fourth section presents and analyzes the inventor mobility networks. In this regard the generated networks are linked to the underlying concept of national innovation systems. Through quantification of the two types of knowledge flows, data are generated that is used in the second part of section four to construct a model of knowledge flows and explain them through the use of key influence factors. In the fifth section the results from the conducted analyses of section 4 are critically discussed and the insights gained are measured against real developments, in particular in recent years.

The study concludes with and outlook and future research options in the sixth section.

\section{Literature Review}

The study of inventor mobility networks has been initiated by the seminal work of (Jaffe et al., 1993) which introduced the general concept to economics. The main idea, however, can be found in the knowledge diffusion process at the core of any NIS and thus dates back to the work of (Lundvall, 1992) as well as his predecessors like (Freeman, 1987).

Following the study by (Jaffe et al., 1993) a number of authors took the idea of inventor mobility and developed it with a focus on specific regions. Table 1 summarizes key studies building on the idea of inventor mobility that show a distinct regional focus and two studies that tackle the same underlying questions but from a patent citation perspective.

This sample of studies illustrates that the main focus of these type of studies lies on Europe which seems reasonable considering the short distances across Europe and the freedom of movement and labor across the European Single Market. Additionally, EPO secondary patent data are more readily available than SIPO or other national data sources and using a none national data source for analysis like (Alnuaimi et al., 2012) or this study follow always runs the risk of underrepresenting actual knowledge flows.

Aside from studies with a regional focus, a number of studies also develop a distinct sectoral focus. Table 2 summarizes a select number of studies where such a distinct focus can be found. 


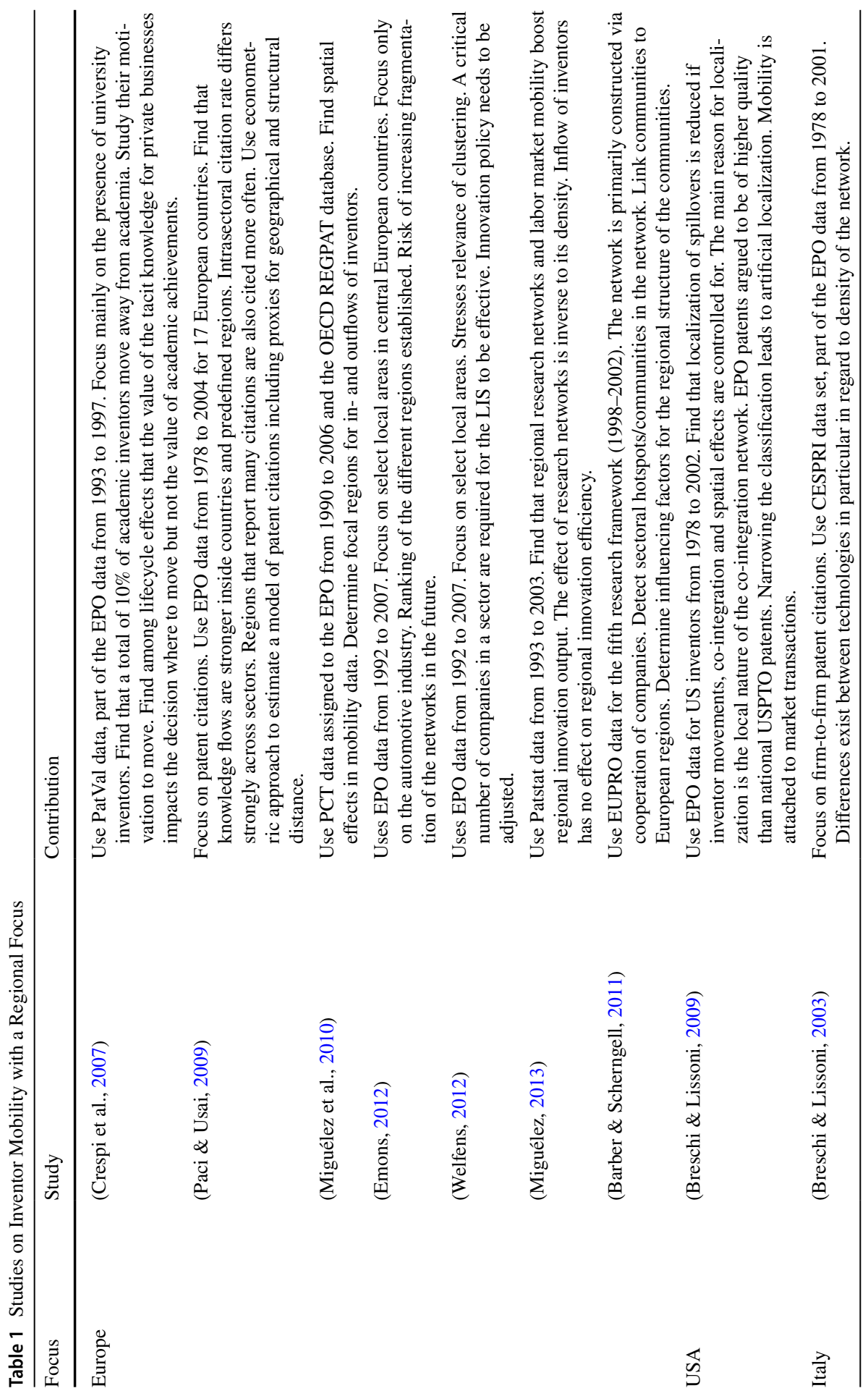




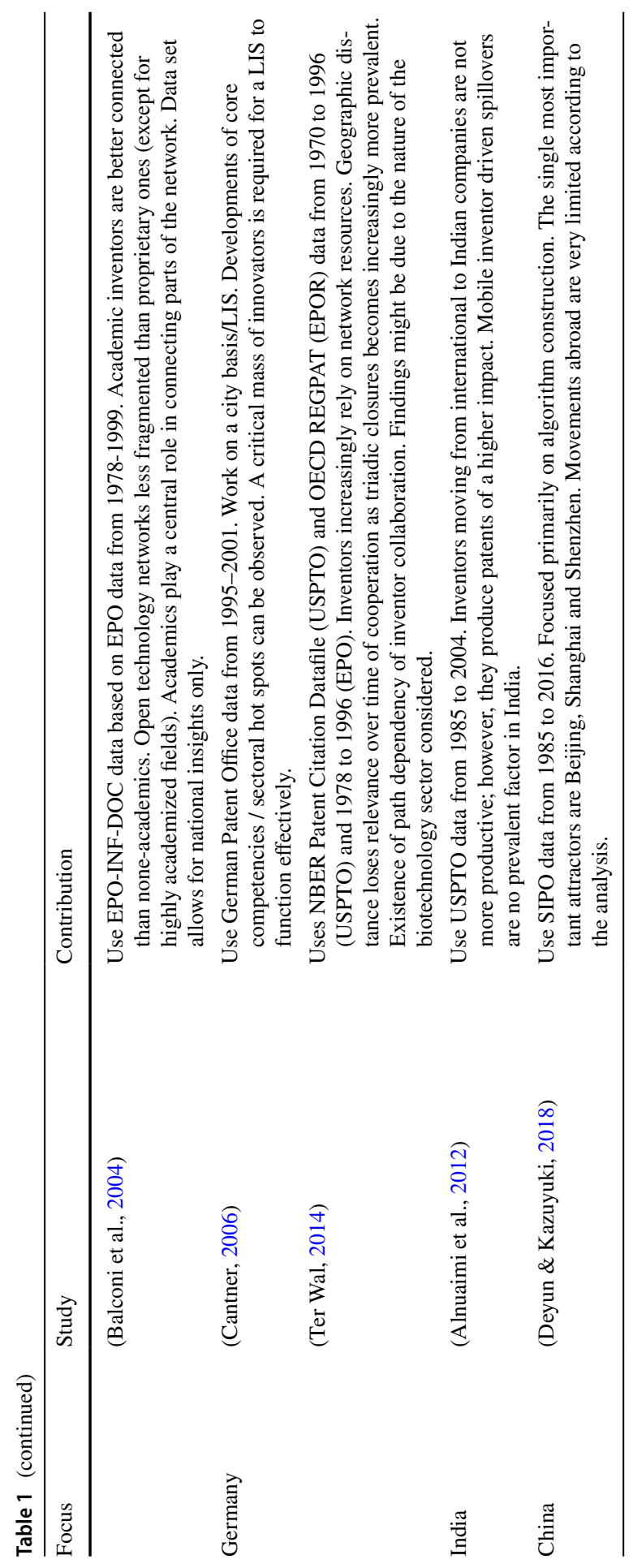


Table 2 Studies on Inventor Mobility with a Sectoral Focus

\begin{tabular}{lll}
\hline Focus & Study & Contribution \\
\hline Biotechnology & (Breschi \& Lissoni, 2009) & See Table 1. \\
& $($ Ter Wal, 2014) & See Table 1. \\
Automotive & (Ploder et al., 2010) & Use EPO data from 1988 to 2005. \\
& & Network becomes denser over \\
& & time. Temporal and national \\
& & differences between the sub- \\
& (Emons, 2012) & networks. \\
Drugs & (Breschi \& Lissoni, 2009) & See Table 1. \\
ICT & (Welfens, 2012) & See Table 1. \\
Healthcare & (Welfens et al., 2011) & See Table 1. \\
& & Use EPO data from 1992 to \\
& & 2007. Focus on local innovation \\
& & systems in two select countries. \\
& & Misses links with other critical \\
\hline
\end{tabular}

If a more critical perspective is taken again, it can be seen that the main focus lies on European authors focusing on sectors that are of importance for the Central European countries in particular.

Finally, the study (Hoisl, 2007) can be mentioned which presents a study on the implications of inventor mobility, especially concerning productivity. Thus, compared to the other studies above (Hoisl, 2007) treats inventor mobility not as an independent concept but considers it as an initiator of productivity. (Hoisl, 2007) thus complements this study where drivers of inventor mobility are discussed.

This overview show two things. First, in recent literature on inventor mobility the RF is not considered at all. Therefore, a research gap exists that is important not only from a regional perspective. Even more important from a Russia centric perspective insights into the workings of the Russian NIS can be gained which offer policymakers as well as domestic and foreign investors insights into the flexibility of knowledge carriers. Additionally, building on the arguments in (Hoisl, 2007) a link exists between inventor mobility and productivity thus the development of inventor mobility networks can generate insights into this vital driver of Russian productivity aside from classical drivers like the oil and gas industry or foreign capital transfers.

While inventor mobility in a Russian context has not been considered before (Perret, 2015) presents a study that considers the Russian perspective on interregional knowledge flows from a patent citation perspective. In addition to Table 3 summarizes a sample of relevant publications on the topic of inner-Russian labor mobility, with a focus on human capital movements in particular. The summary comprises studies focusing on the topic of international movements of human capital as considered in the context of the brain drain versus brain circulation debate as well as domestic interregional and intersectoral movements.

They show that pull and push factors that have already been noted in the context of the studies on inventor mobility above apply for human capital movements 
Table 3 Studies on Human Capital Mobility within the Russian Federation

\begin{tabular}{|c|c|}
\hline Study & Contribution \\
\hline (Piskunov \& Lenshin, 1992) & $\begin{array}{l}\text { No empirical basis. Emigration is due to low standard of living and social } \\
\text { crisis. Emigration patterns are adjustments to international migration } \\
\text { patterns. Calls for regulation of migration and establishment of suit- } \\
\text { able research infrastructure. Emigration might pose a threat to global } \\
\text { security. }\end{array}$ \\
\hline (Ledeneva, 2002) & $\begin{array}{l}\text { Uses survey data from } 2000 / 2001 \text { from students aged } 19 \text { to } 35 \text { studying } \\
\text { abroad in the US or Europe. Majority wants to continue studying or } \\
\text { working abroad. Students miss professional opportunities in Russia. } \\
\text { Need for a returnee program. }\end{array}$ \\
\hline
\end{tabular}

(Andrienko \& Guriev, 2004) Uses panel data from 1992 to 1999 on region-to-region movements. Movements from poorer to richer regions with better job chances but a poverty-based lock-in is present. Dissolution of previously enforced habitation rules.

(Ivankhnyuk, 2006)

Survey with professors and researchers at Moscow universities. The main professional reasons are wages, declining job prestige and opportunities with the main social reason being social and economic stability and outlook. Survey with 465 graduate students in 2003. Only $24 \%$ would want to work permanently in Russia but $51 \%$ prefer to stay in Russia. Survey with 250 scholars in 2005 . Only $15 \%$ prefer long-term migration to the West. Call for restructuring the R\& D sector and R\& D funding.

(Petrachenko, 2007)

Brain drain is related to national security.

(Mitin , 2011)

No empirical basis. Attraction of hosts exceeds real needs. Preference of human capital to stay at home. Want for better pay and housing, better work equipment. Human capital requires more attention and respect from the state. Call for a government program to regulate migration.

(Latova \& Savinkov , 2012) Distinction between researchers returning to their homeland and brain drain. Reasons for migration include low wages, poor housing, lack of scientific equipment, lack of career opportunities and loss of social prestige. Brain drain significantly decreased over time. $65-85 \%$ of all student studying abroad leave Russia permanently.

(Erokhina, 2014)

No empirical basis. Mobility is both a challenge and an opportunity for Russia. Mobility enforces the need to become more competitive.

(Indukaev at al., 2014)

Scientist mobility analysis based on Web of Science data from 19902012. Decrease in absolute publications in recent years also due to reduced publications in total. Estimating of transition matrix. International affiliation is beneficial for citations. Researchers not moving a lot provide better publications.

(Naumova, 2014)

(Chepurenko, 2015)

Recapitulation of the extent of the emigration of human capital from Russia.

Survey from 2004 to 2005 and interviews from 2005 and 2012. In the 2000 s it is mostly brain circulation not drain. Motivation to leave is primarily the access to research equipment and working in top-level research. International experience increase the quality of the output via better networks. Motivation for establishing national centers of excellence.

(Dezhina, 2015)

Uses OECD data from 2000 to 2009. Intersectoral mobility in Russia is very weak in both directions. Reasons for this include low quality and age of academic researchers. Presents government approach to counter this trend. 
Table 3 (continued)

\begin{tabular}{ll}
\hline Study & Contribution \\
\hline (Markova et al., 2016) & Use Web of Science data from 2008 to 2013. Consider three types of \\
& mobility: Organization, Country, Sector. Citation levels converge to \\
& the host country. Mobile researcher publish more and of higher quality. \\
& Level of scientific development as pull factor. \\
(Dyachenko, 2017) & Uses Web of Science data from 2009. Estimates networks of incoming \\
& scientists and their origins. Estimates networks of scientist mobility \\
& inside Russia, mostly towards Moscow. \\
Use Mathscience data on USSR mathematicians cooperations from 1992 & to 2014. Estimate cooperation networks internationally and with a focus \\
on Mexico. Collaborations are not always with country of origin. & Use Scopus data from 1998 to 2017. Research productivity growth is \\
not accompanied by an increase in funding and R\& D personnel even \\
decreases. Most research and publishing done in central regions. \\
Use Scopus data from 2000 to 2018. Multiple affiliations boost publica- \\
tion activity and quality of publications. About 20\% of publications are \\
only weakly linked to Russia.
\end{tabular}

in general. In an international comparison in particular with industrialized Western countries motivates that labor movements in the RF in general are more limited; with most movements patterns pointing toward the larger Moscow area or abroad (Andrienko \& Guriev, 2004) or (Ledeneva, 2002).

Summarizing, this study provides to the academic base in three ways. First, it offers an initial analysis of inventor mobility across all regions of the RF spanning the period 1992-2008 and thus the full frame of the early transition years up to the economic financial crisis of 2008. It therefore provides additional information on tacit knowledge flows inside an economy where human capital movements were still limited, add least economically. It illustrates the strong uni-directionality of the knowledge flows. Second, it determines theoretically and empirically which factors contribute to the inflow and outflow of inventors into a region. Finally, it establishes that while the Russian economy is mainly resource oriented in the considered time frame its knowledge economy and thus its NIS is still functional.

\section{Methodology}

\section{On the Construction of Inventor Mobility Networks}

Inventor mobility networks allow for a tacit knowledge-oriented point of view on the transfer of knowledge.

Inventor mobility is understood as the situation when a person is listed in at least two different patents, usually issued at two different points in time and his affiliation has changed from one applicant to another. In other words, an inventor has been working at one firm resulting in a first patent and later on worked at a different firm resulting in a second patent. 
Inventor mobility in the implemented context is therefore the typical form of a tacit knowledge spillover. ${ }^{4}$ However, inventor mobility as an analytical tool is not without problems. While it is correct to assume that the movement of an inventor to another firm measured through inventor mobility networks describes a tacit knowledge spillover, knowledge spillovers through the movement of researchers can also take place without any resulting patents. Existing network structures are therefore only the top of the iceberg that is visible through the codified traces of actual knowledge spillovers.

Nevertheless, aside from surveys or analyses of researcher migration and employment developments like the movement of star researchers ${ }^{5}$ which is more or less only important for firms with a high share of academic oriented research and development, an analysis of inventor mobility is one of the few suitable approaches aimed at capturing tacit knowledge spillovers.

Mathematically, the ideas behind inventor mobility networks are taken from social network analysis or more specifically graph theory. (Breschi \& Lissoni, 2004) besides others provide an introduction on the methodology in this context.

Starting with a list of all the patents issued during a specific time horizon-here from 1992 to early 2008, sector and region, an intermediate matrix $M$ is generated that contains as rows the inventors $V_{i=1, \ldots, I}$ and as columns the applicants $A_{j=1, \ldots, J}$. Each cell of the matrix $m_{i, j}$ contains the number of times that inventor $V_{i}$ is mentioned in a patent by applicant $A_{j}$. The final adjacency matrix $Q$ is calculated as $Q=M^{T} M$. The resulting matrix $Q$ is an $J \times J$ matrix, with $J$ the amount of applicants and each column and row representing one specific applicant. Every non-zero entry $q_{i, j}$ represents the researchers that switched from applicant $i$ to applicant $j$. Specifically the $q_{i, j}$ give the number of patents a researcher has been working on in the row-firm at one time and at the column-firm at a later time. Therefore, the $q_{i, j}$ report the number and intensity of spillovers that take place in the observed network. Figure 1 illustrates this procedure as a flowchart.

\section{A Descriptive Approach to Inventor Mobility}

Inventors can become mobile for two fundamental reasons. As introduced in the previous section inventor mobility boils down to an inventor being listed in a patent granted to an applicant registered in one region and later on being listed in another patent granted to an applicant registered in another region.

It should be noted that the applicants of both patents can coincide. Therefore, leading on the one hand to inventor mobility through the movement of an inventor

\footnotetext{
${ }^{4}$ Note that (Verspagen \& Schoenmakers, 2004) differentiates researcher spillovers from inventor mobility; however, their understanding of inventor mobility coincides with the one implemented herein.

5 A star researcher is a scientist that is considered to be among the best researchers in his or her field. In most analyses usually the top 100 or the top 500 researchers are observed. See, for example, (Edler et al., 2008). Note that the term star scientist is sometimes used synonymously to star researcher. Mobility networks of star researchers are constructed similar to those of inventors with the difference that not patents but usually research papers or work places mark the different nodes. The respective networks might overlap with inventor mobility networks if the inventors are also scientifically active.
} 
Fig. 1 Steps in the Construction of Inventor Mobility Networks

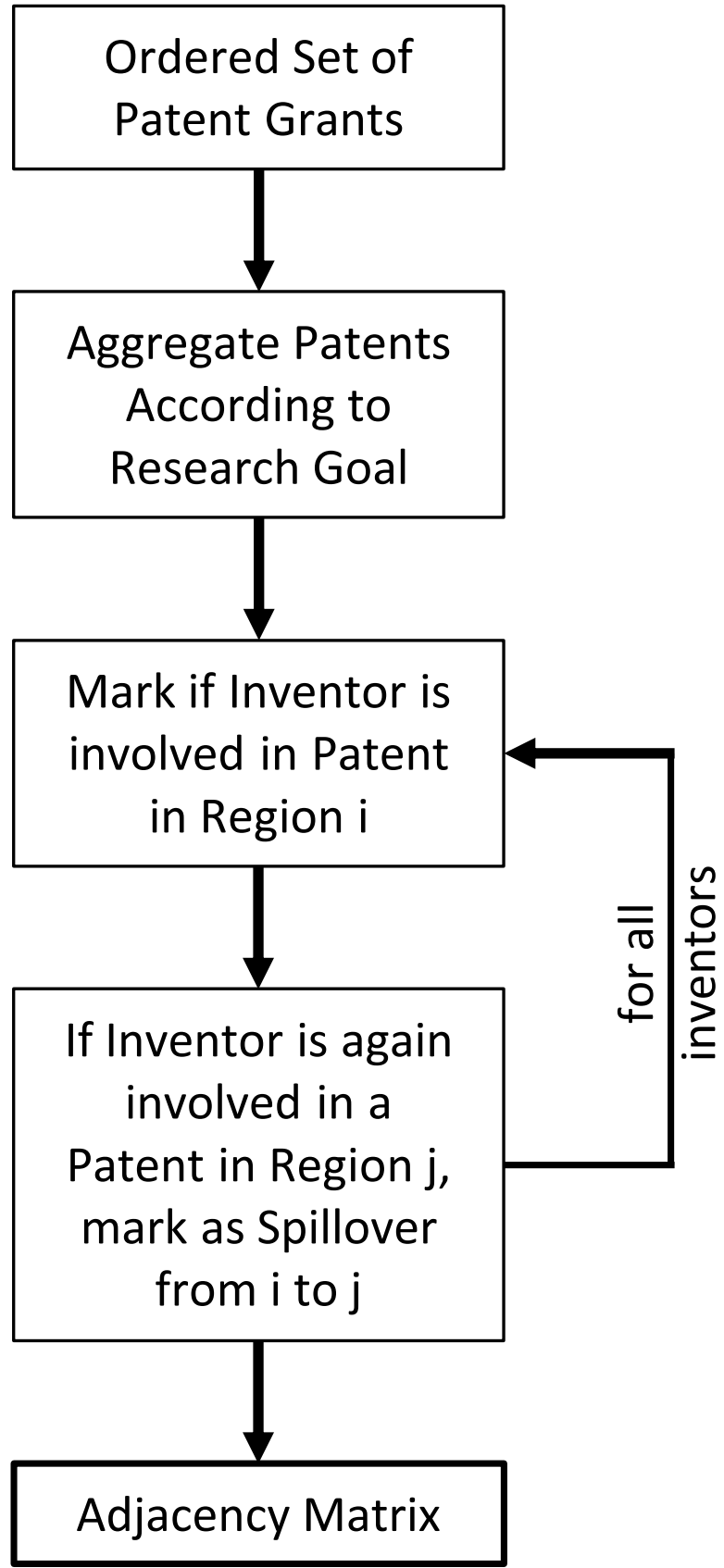

from one firm in one region to another firm in another region and on the other hand to inventor mobility through the movement of a firm from one region to another, while the inventor remains a member of the same firm. For clarity's sake only the 
first type of inventor mobility is considered herein and general inventor mobility networks are cleansed of inventor movements via firm relocations.

To generate the inventor mobility networks observed herein patent data from the European Patent Office has been used. ${ }^{6}$ The data have been taken from the Patstat database. The database has been available up to early 2008 and from the first patent issued with a Russian inventor listed in 1987. It therefore spans the years 1987 to 2008 and a total of 3,589 patents. However, in the course of this study only patents from the 1992 to 2008 have been implemented-excluding all patents issued while Russia was still part of the Soviet Union. The patent basis therefore reduces to 3,562 patents. $^{7}$

Patents used herein represent patent grants instead of patent applications; the dates considered are priority dates. As many of the inventor and applicant addresses have only been available on a country or a regional basis patents have been aggregated on a regional level using the official Russian classification of regions. ${ }^{8}$

Due to the small amount of patents in general, a dissemination of the data into different technology groups is not seen as prudent. Considering the time horizon two sub-periods are observed, the transition years spanning the years 1992 to 1998 and the later years spanning the years 1999 to 2008. This distinction allows furthermore to study whether inventor movements take place over a shorter or a longer term.

These two sub-periods have been chosen because the first period-transition years_-describes a phase of economic decline ending with the ruble crisis in 1998 while from $1999^{9}$ the Russian Federation entered a period of economic growth. Additionally, in the second period due to rising prices for oil and gas the importance of the natural resources sector became more distinct than it has been in the first period. Third, from a political point of view the first period can be seen as a rather chaotic period of declining socialism, economic transition, privatization and degovermentalization ${ }^{10}$, while the second period with the beginning with the start of the presidency of Vladimir Putin has been a phase of overall stabilization and rising state influence. Using data only up to the beginning of 2008 takes place for two main reasons. In 2014 Russia annexed Crimea, taken together with the change in borders between the city of Moscow and the Moscow oblast in 2012 a significant

\footnotetext{
${ }^{6}$ It can be argued that European Patent Office data limit the results of the analysis to those firms that have a general interest in the European market. However, considering that the correlation between the patents at the European Patent Office and the patents at Rospatent across all regions for the ten years from 1997 to 2006 amounts to 0.9245 it can be assumed that distribution of international patents across regions mirrors that of domestic patents which should be less biased towards the European market. Nevertheless, a suitable way to complement this study would be to use triad patents or at least Japanese or Chinese patent data; thereby covering for possible patenting in the Far Eastern regions which might be more oriented towards Asian markets than towards the European market.

${ }^{7}$ It can be noted that the results in the following sections do not change, even if patents from Soviet Russia were used.

8 The Nenetsia Autonomous Okrug is considered part of the Arkhangelsk Oblast and the Yamalia and Khantia-Mansia Autonomous Okrugs are considered parts of the Tyumen Oblast.

${ }^{9}$ Following official statistics the economic revival had already started in 1997.

10 Privatization and degovermentalization by themselves are not economically harmful; however, their implementation can be considered to have taken place in a rather chaotic way.
} 


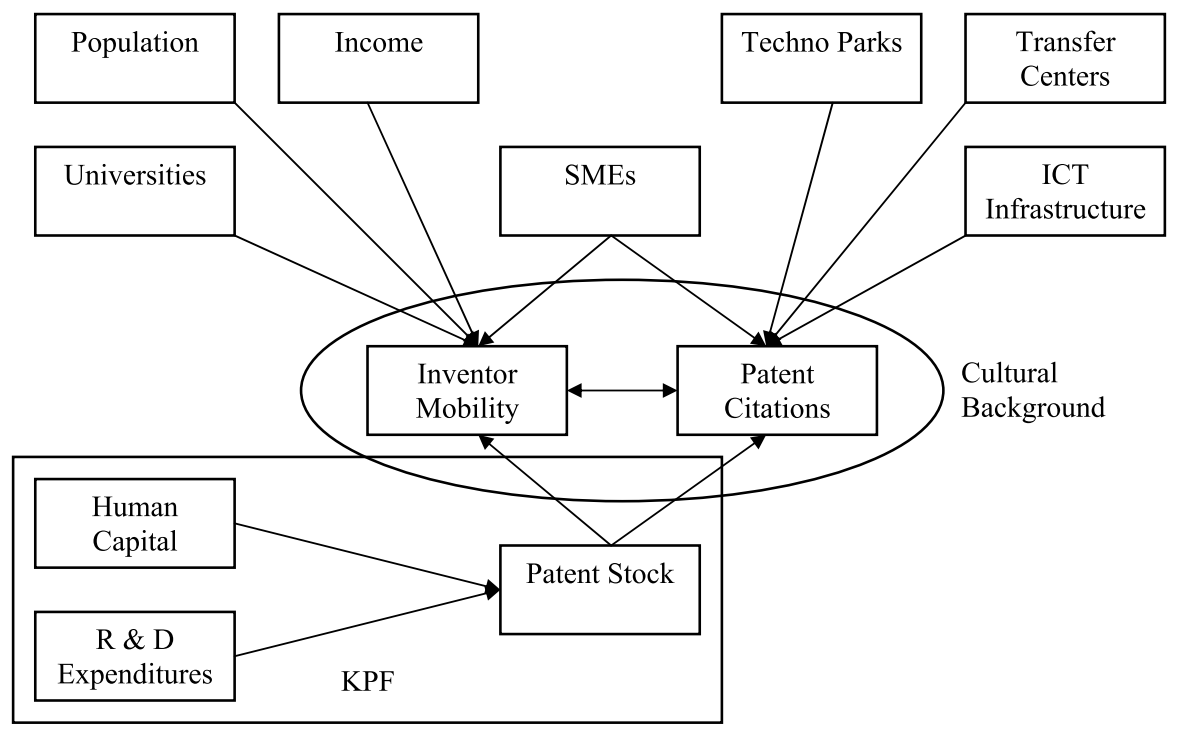

Fig. 2 Basic Model of Knowledge Spillovers

change in the geographical layout of the Russian regions occurred that would have impacted any comprehensive analysis. In particular the change in 2012 would have generated a number of artificial movements. The period of 2008 to 2012 is omitted as this coincided with the Presidency of Dmitry Medvedev but more so would be strongly biased by the negative effects of the economic financial crisis that showed its first effects in Russia by late 2008.

This analysis of inventor mobility in Russia is focused on the Russian perspective therefore only inventors of Russian origin are considered and the assignment of patents to regions is performed on the basis of the inventors' addresses. It can already be noted beforehand that the low amount of patents in general will lead to a limited amount of inventor movements. Additionally, it needs to be considered that mobility of labor across regions of the Russian Federation in general is rather low ${ }^{11}$ leading to the assumption that it will be even lower for inventors. Finally, only few regions are actually focused on research and development-mostly former Soviet research centers like Novosibirsk or Nizhny Novgorod-and therefore offer the potential to generate internationally important patents.

\section{Inventor Mobility in the Context of a NIS}

Figure 2 illustrates the systematic relationship between knowledge spillovers-inventor inflows and outflows - on the one hand and knowledge inputs as well as tertiary variables on the other. It provides the structure chosen to drive the analysis in this section.

11 See for example the points mentioned in this context by (Andrienko \& Guriev, 2004). 
While the model in Fig. 2 is very detailed, for reasons of simplicity and data availability the cultural background and the dynamics with regard to the knowledge production process are omitted. Aside from the cultural background the industrial structure is considered to have an influence. It is modeled using the share of small and medium-sized enterprises. While small and medium enterprises are more flexible and supposedly more open to new ideas and knowledge sharing in general, knowledge sharing across small and medium enterprises should be more pronounced than across larger enterprises because researchers might be more inclined to leave smaller firms in favor of larger ones as those might be able to offer them more favorable working conditions and better incomes. Additionally, in economically unstable times and in a society where small and medium enterprises are discriminated against, although not officially by the law but by its implementation, large firms might offer workers in general better long-term job security. However, using the share of small and medium enterprises as an independent variable might be superfluous as an application for a European Patent Office patent is rather cost intensive in itself and therefore mostly only larger firms can afford to have their inventions patented internationally or might even be interested in orienting themselves internationally towards the European market.

The amount of foreign direct investment inflows in some part reflects the industrial structure of a region as well, but it controls for a number of additional aspects as well. It indirectly reflects investment climate in a region or more precisely its practical effectiveness as well as income potential and competition as foreign owned firms potentially pay higher wages and due to their usually higher technology levels they are more competitive. The presence of foreign owned firms also represents the demand for highly qualified labor and might through this channel attract qualified researchers.

The investment climate as well as some part of the overall living conditions are also controlled for by including a variable for the share of the shadow economy. ${ }^{12}$

Additionally, spillover activities are influenced by newly generated knowledge. From the point of knowledge generation and diffusion enhancing institutions detailed data on institutions that might have a direct impact on knowledge diffusion like techno parks, research and technology information centers, centers for technology transfer and centers for joint enterprises are not available for more than one year.

Nevertheless, information on the stock of available knowledge is available by construction of a patent stock. The stock of knowledge is calculated as a sum of the patents granted in the last ten years using a linear depreciation scheme for weights. As patent data at the European Patent Office are available since 1987 it is also no problem to generate a long enough time series. ${ }^{13}$ Aside from the fact that the spillover variables are based on patent grants by the European Patent Office, the

\footnotetext{
12 The indicator has been calculated using the electricity method used for example in a similar context by (Johnson et al., 1997).

13 Note that the first years 1994 and 1995 include only the last eight or nine years in the calculation of their stock of patents, respectively.
} 
possibility to generate a consistent stock of patent for most of the respective time periods is one of the main reasons to include only patent data from the European Patent Office.

To differentiate between the innovative situation in the region and its past situation besides the patent stock, which describes more or less the past situation, current patent grants for the region can also be included as explanatory variables.

(Coe \& Helpman, 1993) as well as (Keller, 1998) argue that the trade pattern-the specialization in different goods-is important for spillover activities; however, disaggregated data are not available for the whole time period. Instead, the amount of exports and imports as well as the degree of openness of a region are introduced into the model. They are used to control for the openness and in some part the backwardness of a region. As (Funk, 2001) puts it, the distance from the technological frontier has a positive effect on knowledge flows and therefore the intensity of knowledge spillovers. Here it is assumed that a technologically advanced region should have high exports and potentially low imports or at least only low-tech imports.

Finally, the two basic knowledge input variables-researchers and R\&D expenditures - can be included into the model as well as the gross national product per Capita for controlling for the economic size and wealth of the region as a richer region might attract research personnel through income incentives. The number of students is included as a control variable as the number of future researchers recruit from this stock.

Due to the obvious correlation between a number of the independent variables, problems with multi-collinearity are to be expected. Testing revealed that if the current amount of patent grants and the expenditures on R\&D are left out qualitative statistics like the $\mathrm{R}^{2}$ or the F-statistic remain basically unchanged, while value inflation factors are drastically reduced eliminating most problems with multi-collinearity.

Additional testing revealed that for inventor inflows as well as outflows both the fixed and the random effects model are appropriate. To account for a number of region specific effects, like the distance to Moscow and the regional size, fixed effect models are considered.

Furthermore, a Hausmann test indicates a problem with heteroscedasticity in the error terms. Therefore, only robust standard errors are used.

The Woolridge test for panel data reveals that for the inflow of inventors serial autocorrelation is present in the model indicating potential path dependency of the spillovers.

The Levin-Lin-Chu test shows that no consistent problems due to non-stationary variables exists.

Finally, testing for spatial autocorrelation effects by use of a Lagrange multiplier test reveals that the outflow of inventors reports a significant spatial lag structure. In none of the two models a spatial error structure is present. For the outflow of inventors a link test indicates a wrong model structure, which might be an additional sign that the serial or spatial autocorrelation effects in these models could be considerable. Additionally, the use of a general least squares or general methods of moments 
Table 4 List of Variables and their Sources

\begin{tabular}{|c|c|c|c|}
\hline Abbreviation & Variable & Unit & Source \\
\hline CONST & Constant & - & - \\
\hline GRPPC & Gross Regional Product per Capita & Constant US\$ & $\begin{array}{l}\text { Rosstat (2012), Surinov (1999), } \\
\text { World Bank (2012) }\end{array}$ \\
\hline EX & Exports & Constant US \$ & Rosstat (2012) \\
\hline IM & Imports & Constant US \$ & Rosstat (2012) \\
\hline INMOIN & Inflows of Inventors & - & European Patent Office (2007) \\
\hline INMOOU & Outflows of Inventors & - & European Patent Office (2007) \\
\hline LAGT-1 & $\begin{array}{l}\text { One Year Laggeg Dependent Vari- } \\
\text { able }\end{array}$ & - & - \\
\hline OPEN & Openness (EX+IM)/GRPPC & - & $\begin{array}{l}\text { Own calculations and Rosstat } \\
\text { (2012) }\end{array}$ \\
\hline PATSTO & Stock of Patents at the EPO & - & European Patent Office (2007) \\
\hline RES & Researchers & - & Rosstat (2012) \\
\hline SHADOW & Share of Shadow Economy & - & $\begin{array}{l}\text { Own calculations and Rosstat } \\
\text { (2012) }\end{array}$ \\
\hline SME & $\begin{array}{l}\text { Share of Small and Medium sized } \\
\text { enterprises }\end{array}$ & - & Rosstat (2012) \\
\hline STUD & Number of Students & - & Rosstat (2012) \\
\hline TRDUM & $\begin{array}{l}\text { Dummy Variable for Transition } \\
\text { Years }\end{array}$ & - & - \\
\hline$\lambda$ & Spatial Lag Effects & - & - \\
\hline
\end{tabular}

estimator instead of a zero-inflated Poisson or negative binomial estimator might be the cause for the faulty model structure ${ }^{14}$. Furthermore, both models suffer from omitted variables according to the Ramsey test, which might be variables on the cultural and institutional infrastructure that could not be included into the model.

The abbreviations used in the presentation of the regression results are summarized in Table 4.

\section{Inventor Mobility Flows across the Russian Federation}

Figure 3 shows the inventor movements over the time period 1992 to 2008 realizing thus the discussed approach from the previous section for data on Russian inventors.

In the figure the undirected inventor mobility is shown across the regions of the Russian Federation and every edge in the network represents the movement of at least one inventor. The thickness of the edges reports the number of inventors and moved along this edge. A undirected graph has been selected as it simplifies the readability of the figure and only diminishes the insights marginally as only the links

\footnotetext{
14 The large amount of regions with no spillovers at all is a good indicator for the presence of zeroinflation.
} 


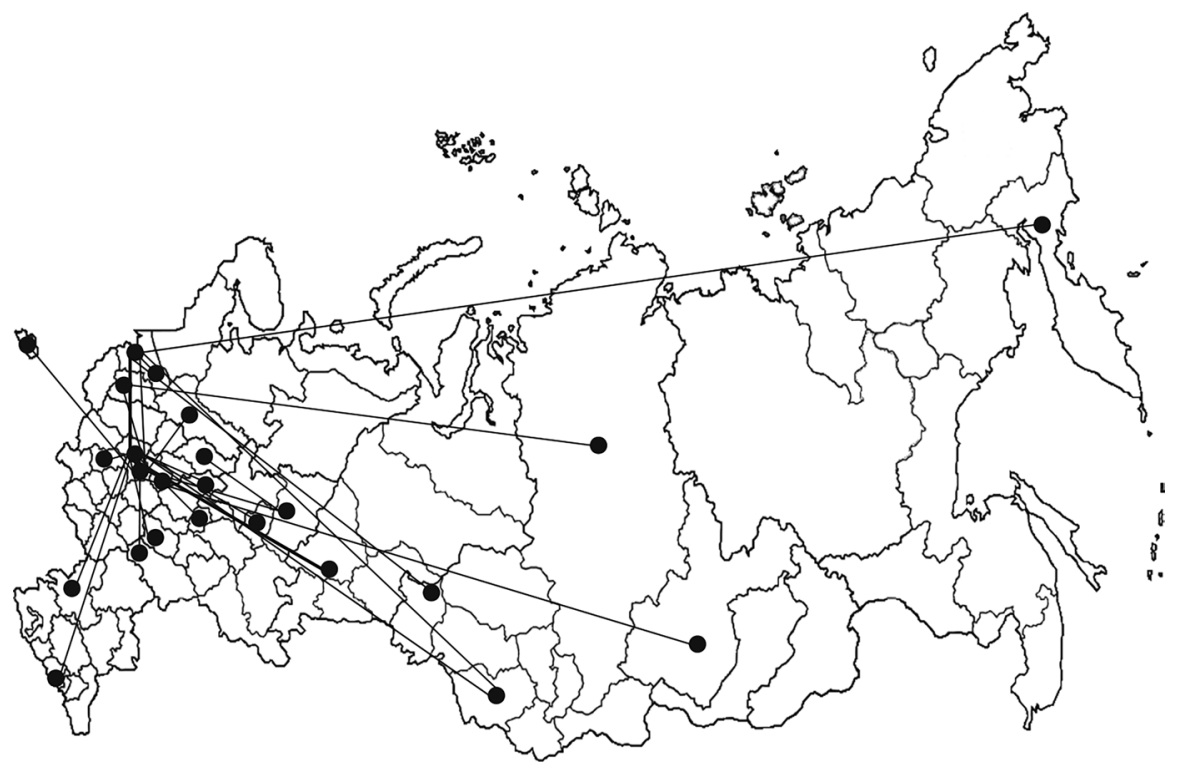

Fig. 3 Inventor Mobility across the Regions of the Russian Federation 1992-2008

between Moscow and St. Petersburg as well as the between Moscow and the Moscow oblast report two-way mobility.

While only 24 regions are marked in the figure (black dots), an additional 19 regions exist where inventor movements took place within the region's borders alone (not marked in the figure) leading to a total of 43 regions - approximately half of all regions-that report inventor mobility. However, the region's importance as measured by their integration into the network as well as their links with other regionstheir degree-differs significantly. Consequently, to illustrate these differences and as the focus of this study interregional all regions in which only intraregional movements took place have been excluded.

Unsurprisingly enough the strongest links and therefore the highest levels of inventor mobility are present between three main regions which are incidentally the two federal cities Moscow and St. Petersburg as well as the Moscow oblast which is essentially an extension of the city of Moscow.

Nevertheless, spillovers take place not only between these three major regions, but also with them and a number of other regions. While spillovers from and to typical innovative industrialized regions or regions with inherently close links to the three majors like the Leningrad, Novosibirsk and Vladimir oblasts can easily be explained, the significant spillovers in the context of the Voronezh oblast and the republic of Udmurtia might only become clear through a deeper analysis.

As such the Leningrad oblast profits from its proximity to the city of St. Petersburg in the same way as the Moscow oblast from its proximity to Moscow. For a number of firms and inventors it is more convenient to move to the outlying oblast as for example rents there are much cheaper. To a lesser degree the so-called proximity-to-Moscow-effect holds true for regions like the Vladimir oblast as well. 
Novosibirsk, however far away from the capital, has profited in the last decades and still does profit from having already been an important industrial cluster region in Soviet times with a large amount of research taking place there which in many respects has prevailed until today.

Considering the connection diversity the Krasnoyarsk krai, as a natural resource oriented region, and the Ryazan and Penza oblast as well as the Altai krai, as rather less developed regions, are part of the network as well.

The regions of the Northern Caucasus as well as the regions of the Far East arewith only one exception each-totally absent from the figures. In a few cases they report internal spillovers.

Finally, it can be noted that Fig. 3 reports only pure inventor movements. However, the amount of inventor movements due to firm relocations is only of marginal significance and firm relocations mostly affect intraregional spillovers. It can additionally be acknowledged that the underlying firm-to-firm network is comparatively sparse like the one presented by (Alnuaimi et al., 2012) for India and a comparatively long timeframe that was based on USPTO patents. Thus, a structure as witnessed above might be telling for transition countries.

\section{Explaining Inventor Flows}

Using the results from the graphical analysis of the inventor movements as presented in the previous section, an econometric model is estimated that represents the analytical approach as displayed in Fig. 2 and discussed in the corresponding section. This analysis thus links the descriptive graph theoretical approach of the previous section to the economic concept of NIS.

Tables 5 and $6^{15}$ summarize the results for inventor inflows in a dynamic spatial lag and a dynamic Durbin model ${ }^{16}$. The variables implemented in this estimation are summarized in Table 4 and discussed accordingly in the corresponding section. In all subsequent tables the values in parentheses give the corresponding t-statistic and the asterisks indicate the signficance level of the corresponding coefficients; * indicates a significance level of $10 \%, * *$ a significance level of $5 \%$ and $* * *$ a significance level of $1 \%$.

As the results for the total time period are in many parts inconclusive, the whole period is divided into the transition years up to 1998 and the later years from 1999 onwards.

Considering the model structure two types of models have been estimated; a Spatial Lag Han-Philips Linear Dynamic Panel Data Regression and a Spatial Durbin Han-Philips Linear Dynamic Panel Data Regression to include two types of spatial effects. Here it has been shown that the results are more or less the same with only minor differences in the size of the coefficients. Both estimators are based on a Blundell-Bond system estimator. Using these estimators allows to control for serial

\footnotetext{
15 If any statistic exceeds 1,000 , its last three zeros are abbreviated as $k$ while if it exceeds $1,000,000$ its last six zeros are abbreviated as $M$.

16 In a Durbin model additional spatially lagged independent variables are introduced into the model.
} 
Table 5 Inventor Inflows-Part I

\begin{tabular}{|c|c|c|c|c|c|c|}
\hline & \multicolumn{3}{|l|}{ Lag-Model } & \multicolumn{3}{|l|}{ Durbin-Model } \\
\hline & I & II & III & I & II & III \\
\hline LAGT-1 & $\begin{array}{l}0.3359 \\
(1.11)\end{array}$ & $\begin{array}{l}0.5646 \\
(1.45)\end{array}$ & $\begin{array}{l}0.0670 \\
(0.80)\end{array}$ & $\begin{array}{l}0.3321 \\
(1.11)\end{array}$ & $\begin{array}{l}0.5837 \\
(1.50)\end{array}$ & $\begin{array}{l}0.0656 \\
(0.82)\end{array}$ \\
\hline RES & $\begin{array}{l}0.5624 * * * \\
(4.38)\end{array}$ & $\begin{array}{l}0.7860 * * * \\
(10.84)\end{array}$ & $\begin{array}{l}0.1857 * * * \\
(5.37)\end{array}$ & $\begin{array}{l}0.5854 * * * \\
(4.53)\end{array}$ & $\begin{array}{l}0.8132 * * * \\
(10.60)\end{array}$ & $\begin{array}{l}0.2028^{* * * *} \\
(5.53)\end{array}$ \\
\hline GRPPC & $\begin{array}{l}0.1950 \\
(0.03)\end{array}$ & $\begin{array}{l}-61.6000^{* * * *} \\
(-3.18)\end{array}$ & $\begin{array}{l}-3.6500 \\
(-1.40)\end{array}$ & $\begin{array}{l}2.5400 \\
(0.29)\end{array}$ & $\begin{array}{l}-48.5000^{*} \\
(-1.84)\end{array}$ & $\begin{array}{l}-2.7100 \\
(-0.88)\end{array}$ \\
\hline PATSTO & $\begin{array}{l}0.0072 \\
(0.40)\end{array}$ & $\begin{array}{l}-0.0672 * * \\
(-2.53)\end{array}$ & $\begin{array}{l}0.1362 * * * \\
(14.03)\end{array}$ & $\begin{array}{l}0.0059 \\
(0.33)\end{array}$ & $\begin{array}{l}-0.0759 * * * \\
(-2.74)\end{array}$ & $\begin{array}{l}0.1317 * * * \\
(12.90)\end{array}$ \\
\hline SME & $\begin{array}{l}1.2468 \\
(0.66)\end{array}$ & $\begin{array}{l}-0.0266 \\
(-0.02)\end{array}$ & $\begin{array}{l}-0.2356 \\
(-0.48)\end{array}$ & $\begin{array}{l}1.3798 \\
(0.72)\end{array}$ & $\begin{array}{l}0.8192 \\
(0.63)\end{array}$ & $\begin{array}{l}-0.2090 \\
(-0.40)\end{array}$ \\
\hline TRDUM & $\begin{array}{l}-0.1743 \\
(-0.45)\end{array}$ & & & $\begin{array}{l}0.1769 \\
(1.14)\end{array}$ & & \\
\hline$\lambda$ & $\begin{array}{l}0.2801 \\
(0.94)\end{array}$ & $\begin{array}{l}0.1405 \\
(0.67)\end{array}$ & $\begin{array}{l}0.0022 \\
(0.02)\end{array}$ & & & \\
\hline$\lambda \mathrm{RES}$ & & & & $\begin{array}{l}1.6569 \\
(1.14)\end{array}$ & $\begin{array}{l}1.8244 * * \\
(2.28)\end{array}$ & $\begin{array}{l}0.7413 \\
(1.43)\end{array}$ \\
\hline$\lambda \mathrm{GRPPC}$ & & & & $\begin{array}{l}-9.5300 \\
(-0.72)\end{array}$ & $\begin{array}{l}77.1000 \\
(1.46)\end{array}$ & $\begin{array}{l}5.8700 \\
(0.95)\end{array}$ \\
\hline$\lambda$ PATSTO & & & & $\begin{array}{l}0.0644 \\
(0.25)\end{array}$ & $\begin{array}{l}-0.5475^{*} \\
(-1.66)\end{array}$ & $\begin{array}{l}-0.2138 \\
(-1.27)\end{array}$ \\
\hline$\lambda \mathrm{SME}$ & & & & $\begin{array}{l}-16.1563 * * \\
(-2.29)\end{array}$ & $\begin{array}{l}-19.3383 \text { *** } \\
(-2.75)\end{array}$ & $\begin{array}{l}-5.3767 \\
(-1.58)\end{array}$ \\
\hline CONST & $\begin{array}{l}-0.9127 \\
(-1.15)\end{array}$ & $\begin{array}{l}0.0174 \\
(0.14)\end{array}$ & $\begin{array}{l}-0.0031 \\
(-0.03)\end{array}$ & $\begin{array}{l}-2.1287 \\
(-0.47)\end{array}$ & $\begin{array}{l}0.0534 \\
(0.43)\end{array}$ & $\begin{array}{l}0.0119 \\
(0.13)\end{array}$ \\
\hline Adj. $\mathrm{R}^{2}$ & 0.027 & 0.570 & 0.921 & 0.029 & 0.558 & 0.921 \\
\hline F Test & $3.691 * *$ & $159.364 * * *$ & $1 \mathrm{k} * * *$ & $3.057 * *$ & $101.790 * * *$ & $928.911 * * *$ \\
\hline
\end{tabular}

as well as spatial autocorrelation. In regard to the spatial aspect the Durbin estimator in particular considers as well spatial lags in the independent variables. The motivation to use both the lag and the Durbin version of the estimator results from the insights in (Perret, 2013) where it has been argued and empirically shown that both aspects are potential problems when working with knowledge spillovers and inventor mobility in particular.

Both estimators have been applied to a model with control variables (Table 6) and one without (Table 5).

Independent of the model structure, a structural break in the levels of inventor mobility is rather unlikely (the TRDUM variable, marking the transition years is insignificant), whereas the coefficients show that the impact of the different variables changes significantly between the transition and the later years. Even though, the dummy variable for the transition years is insignificant in most model designs its 
Table 6 Inventor Inflows-Part II

\begin{tabular}{|c|c|c|c|c|c|c|}
\hline & \multicolumn{3}{|c|}{ Lag-Model } & \multicolumn{3}{|l|}{ Durbin-Model } \\
\hline & I & II & III & I & II & III \\
\hline LAGT-1 & $\begin{array}{l}0.3480 \\
(1.14)\end{array}$ & $\begin{array}{l}0.6422 \\
(1.22)\end{array}$ & $\begin{array}{l}0.0736 \\
(0.93)\end{array}$ & $\begin{array}{l}0.3420 \\
(1.16)\end{array}$ & $\begin{array}{l}0.7843 \\
(1.63)\end{array}$ & $\begin{array}{l}0.0598 \\
(0.77)\end{array}$ \\
\hline RES & $\begin{array}{l}0.5526^{* * * *} \\
(3.82)\end{array}$ & $\begin{array}{l}0.3270 * * * \\
(3.83)\end{array}$ & $\begin{array}{l}0.1938 * * * \\
(5.42)\end{array}$ & $\begin{array}{l}0.5099 * * * \\
(3.48)\end{array}$ & $\begin{array}{l}0.4713 * * * \\
(5.79)\end{array}$ & $\begin{array}{l}0.2104 * * * \\
(5.65)\end{array}$ \\
\hline GRPPC & $\begin{array}{l}-6.9600 \\
(-0.99)\end{array}$ & $\begin{array}{l}21.6000 \\
(1.11)\end{array}$ & $\begin{array}{l}5.2600 \\
(1.62)\end{array}$ & $\begin{array}{l}1.8300 \\
(0.21)\end{array}$ & $\begin{array}{l}47.5000 * \\
(1.72)\end{array}$ & $\begin{array}{c}12.8000^{* * * *} \\
(2.75)\end{array}$ \\
\hline PATSTO & $\begin{array}{l}0.1739 * * * \\
(5.37)\end{array}$ & $\begin{array}{l}0.1100 * * * \\
(3.81)\end{array}$ & $\begin{array}{l}0.1603 \text { *** } \\
(11.83)\end{array}$ & $\begin{array}{l}0.1676^{* * * *} \\
(4.78)\end{array}$ & $\begin{array}{l}0.0763^{* * * *} \\
(2.70)\end{array}$ & $\begin{array}{l}0.1523^{* * *} \\
(10.83)\end{array}$ \\
\hline SME & $\begin{array}{l}1.2876 \\
(0.77)\end{array}$ & $\begin{array}{l}0.2454 \\
(0.19)\end{array}$ & $\begin{array}{l}-0.0779 \\
(-0.14)\end{array}$ & $\begin{array}{l}2.0097 \\
(1.16)\end{array}$ & $\begin{array}{l}0.5983 \\
(0.51)\end{array}$ & $\begin{array}{l}-0.0788 \\
(-0.14)\end{array}$ \\
\hline EX & $\begin{array}{l}-0.0066^{* * * *} \\
(-7.03)\end{array}$ & $\begin{array}{l}-0.0049 * * * \\
(-4.67)\end{array}$ & $\begin{array}{l}-0.0023 * * * \\
(-4.69)\end{array}$ & $\begin{array}{l}-0.0068 * * * \\
(-7.11)\end{array}$ & $\begin{array}{l}-0.0066^{* * * *} \\
(-6.77)\end{array}$ & $\begin{array}{l}-0.0028 * * * \\
(-4.78)\end{array}$ \\
\hline IM & $\begin{array}{l}0.0089 * * * \\
(13.53)\end{array}$ & $\begin{array}{l}0.0098 * * * \\
(14.01)\end{array}$ & $\begin{array}{l}-0.0059^{* *} \\
(-2.27)\end{array}$ & $\begin{array}{l}0.0087 * * * \\
(13.11)\end{array}$ & $\begin{array}{l}0.0096^{* * * *} \\
(14.55)\end{array}$ & $\begin{array}{l}-0.0046 \\
(-1.62)\end{array}$ \\
\hline OPEN & $\begin{array}{l}-0.0046 \\
(-0.92)\end{array}$ & $\begin{array}{l}-0.0047 \\
(-0.79)\end{array}$ & $\begin{array}{l}0.1156^{*} \\
(1.97)\end{array}$ & $\begin{array}{l}-0.0035 \\
(-0.69)\end{array}$ & $\begin{array}{l}-0.0022 \\
(-0.34)\end{array}$ & $\begin{array}{l}0.1524 * * \\
(2.31)\end{array}$ \\
\hline FDI & $\begin{array}{l}0.0060 * * * \\
(3.89)\end{array}$ & $\begin{array}{l}0.0030 * * \\
(2.35)\end{array}$ & $\begin{array}{l}-0.0006 \\
(-0.31)\end{array}$ & $\begin{array}{l}0.0059 * * * \\
(3.78)\end{array}$ & $\begin{array}{l}0.0054 * * * \\
(4.28)\end{array}$ & $\begin{array}{l}-0.0014 \\
(-0.74)\end{array}$ \\
\hline STUD & $\begin{array}{l}-0.0088 \\
(-0.89)\end{array}$ & $\begin{array}{l}-0.0181 \\
(-1.16)\end{array}$ & $\begin{array}{l}0.0004 \\
(0.13)\end{array}$ & $\begin{array}{l}-0.0128 \\
(-1.19)\end{array}$ & $\begin{array}{l}-0.0314^{*} \\
(-1.95)\end{array}$ & $\begin{array}{l}0.0020 \\
(0.53)\end{array}$ \\
\hline SHADOW & $\begin{array}{l}-0.0100 \\
(-0.60)\end{array}$ & $\begin{array}{l}-0.0050 \\
(-0.46)\end{array}$ & $\begin{array}{l}0.0021 \\
(0.40)\end{array}$ & $\begin{array}{l}-0.0145 \\
(-0.85)\end{array}$ & $\begin{array}{l}-0.0052 \\
(-0.34)\end{array}$ & $\begin{array}{l}0.0078 \\
(1.33)\end{array}$ \\
\hline TRDUM & $\begin{array}{l}-0.3549 \\
(-0.96)\end{array}$ & & & $\begin{array}{l}-2.4534 * * * \\
(-2.68)\end{array}$ & & \\
\hline$\lambda$ & $\begin{array}{l}0.0172 \\
(0.06)\end{array}$ & $\begin{array}{l}-0.0112 \\
(-0.05)\end{array}$ & $\begin{array}{l}-0.2096 \\
(-1.39)\end{array}$ & & & \\
\hline$\lambda \operatorname{RES}$ & & & & $\begin{array}{l}-5.6927 \\
(-1.59)\end{array}$ & $\begin{array}{l}4.9616^{* * *} \\
(2.49)\end{array}$ & $\begin{array}{l}0.1552 \\
(0.12)\end{array}$ \\
\hline$\lambda \mathrm{GRPPC}$ & & & & $\begin{array}{l}98.1000 * \\
(1.91)\end{array}$ & $\begin{array}{l}-50.5000 \\
(-0.40)\end{array}$ & $\begin{array}{l}4.2900 \\
(0.11)\end{array}$ \\
\hline$\lambda$ PATSTO & & & & $\begin{array}{l}-0.5001 \\
(-0.86)\end{array}$ & $\begin{array}{l}-0.7173 \\
(-1.02)\end{array}$ & $\begin{array}{l}-0.0711 \\
(-0.10)\end{array}$ \\
\hline$\lambda \mathrm{SME}$ & & & & $\begin{array}{l}-12.5311 \\
(-1.48)\end{array}$ & $\begin{array}{l}-41.7690 * * \\
(-2.56)\end{array}$ & $\begin{array}{l}-30.2178 * * \\
(-2.16)\end{array}$ \\
\hline$\lambda \mathrm{EX}$ & & & & $\begin{array}{l}-0.0211 * * \\
(-2.18)\end{array}$ & $\begin{array}{l}-0.0728 * * * \\
(-3.58)\end{array}$ & $\begin{array}{l}-0.0031 \\
(-0.21)\end{array}$ \\
\hline$\lambda \mathrm{IM}$ & & & & $\begin{array}{l}-0.0092 \\
(-0.98)\end{array}$ & $\begin{array}{l}-0.0052 \\
(-0.50)\end{array}$ & $\begin{array}{l}0.0135 \\
(0.15)\end{array}$ \\
\hline$\lambda \mathrm{OPEN}$ & & & & $\begin{array}{l}0.2051^{* * *} \\
(3.05)\end{array}$ & $\begin{array}{l}0.3012 * * * \\
(3.99)\end{array}$ & $\begin{array}{l}0.7013 \\
(0.39)\end{array}$ \\
\hline$\lambda$ FDI & & & & -0.0100 & $0.0856^{* * *}$ & -0.0082 \\
\hline
\end{tabular}


Table 6 (continued)

\begin{tabular}{|c|c|c|c|c|c|c|}
\hline & \multicolumn{3}{|c|}{ Lag-Model } & \multicolumn{3}{|c|}{ Durbin-Model } \\
\hline & I & II & III & I & II & III \\
\hline & & & & $(-0.37)$ & $(4.17)$ & $(-0.11)$ \\
\hline \multirow[t]{2}{*}{$\lambda$ STUD } & & & & $-0.1304 *$ & $-0.4262 * *$ & 0.0075 \\
\hline & & & & $(-1.72)$ & $(-2.32)$ & (0.09) \\
\hline \multirow[t]{2}{*}{$\lambda$ SHADOW } & & & & $0.2898 *$ & $0.4601 * * *$ & 0.1134 \\
\hline & & & & (1.77) & $(3.07)$ & $(1.08)$ \\
\hline \multirow[t]{2}{*}{ CONST } & -0.7550 & 0.1068 & -0.0376 & 13.6983 & 0.0633 & -0.0007 \\
\hline & $(-0.78)$ & $(0.97)$ & $(-0.42)$ & $(1.27)$ & $(0.49)$ & $(-0.01)$ \\
\hline Adj. $R^{2}$ & 0.232 & 0.611 & 0.923 & 0.243 & 0.692 & 0.926 \\
\hline F-Test & $17.672 * * *$ & $95.072 * * *$ & $718.268 * * *$ & $11.438 * * *$ & $77.782 * * *$ & $427.912 * * *$ \\
\hline
\end{tabular}

sign is consistently negative implying that in the transition years less inflows have taken place per se. This could be an effect of the transition years; it is, however, more likely that it is an artifact from the statistical method implemented as in the transition there weren't yet enough patents registered to establish a sending region.

The researcher variable is consistently positive. The conclusion can therefore be reached that an absolutely speaking well-established research community in a region, represented through a high number of researchers, leads to an inflow of additional inventors, independent whether the transition or the later years are observed. In the transition years this effect is stronger as the coefficient is roughly twice the size of the coefficient for the later years.

Thus, in the transition years the centralistic organization of the Soviet science system still influenced the inventor inflow dynamics. ${ }^{17}$ It is foremost those regions that are already well-established in the science system that draw inventors and lead to a continuing centralization of the scientific society. In the later years this trend diminishes and in some cases even reverses resulting in marginal scientific decentralization. In other words the role of Moscow as the foremost research hub diminishes slightly.

For the gross regional product per capita variable the results vary indicating that it is dependent on the assumed model structure. Assuming the extended model in the second table to be the most comprehensive the coefficients here remain stable even though some are no longer significant. The results here are furthermore in line with an assumed rent-seeking motive of inventors. Inventors would therefore in general be more prone to move to richer regions or regions where they suspect to earn higher wages. ${ }^{18}$

\footnotetext{
17 It is assumed that the central role of Moscow and the Moscow oblast in the Russian science system biases the results significantly. This can be seen from an analysis of the inventor flows as illustrated in Fig. 3 above.

18 Again the city of Moscow and the surrounding oblast might have had a biasing effect on the results.
} 
The patent stock shows an almost consistently positive sign with the transition years being an exception. This might be expected considering the results for the researchers, since a higher amount of patents means on the one hand a better developed science system and on the other a rise of the patent stock inherently means a rise in inventor levels - of which some might be external to the region. Second, while patents from the European patent office have been used in this analysis and the first patents to Russia or the Soviet Union were issued in the late 1980 s in the early 1990 s there simply was no relevant patent stock that could have driven the inventor dynamics.

The positive relation also shows that information or assistance centers that focus on alleviating the patenting process can help directly in rising the patenting activity and thereby indirectly attract additional inventors as well.

Finally, the last aspect, the share of small and medium enterprises reports consistently insignificant signs. Here the already mentioned selection bias due to the high cost of EPO patents seems to be a potential reason inhibiting in particular small companies to register EPO patents keeping with national patents instead.

Only in the transition years the lagged variables report barely insignificant signs, showing that the inventor inflows back then have been slightly more pathdependent, thereby also strengthening the hypothesis that in the transition years the Russian science system has been oriented on former Soviet research clusters.

A last comment can be given concerning the spatial effects, which are consistently insignificant, strengthening arguments in favor of a more growth poleoriented economic policy with regard to the attraction of inventors, as a negative sign implicates that a region whose neighbors attract fewer inventors is itself more prone to attract more inventors.

The second aspect considered in this study are inventor outflows and therefore the mirror image of the previous part of the analysis.

Above, the importance of the regional science system or the regional innovation system for inventor inflows has been stressed. The same concept can be put to work in the context of inventor outflows leading to the two models estimated in Tables 7 and 8 .

Similar to the inventor inflows the difference between the transition years and the later years is mainly in regard to impact sizes and less so in regard to levels. The dummy variable for the transition years becomes significant in the extended lag model, but its size does not differ a lot from the coefficient in the Durbin model. Again the signs are negative in all cases implying that during the transition years per se there have been fewer outflows.

Again, the researcher variable reports a consistently positive sign. The first part shows that in a region with a well-established science system, measured via a high number of researchers, more researchers are available to look for employment in a firm in another region-where the research system is also well established. Inventors are motivated to relocate to more important research facilities that offer them a better infrastructure. Above it has been stated that during the transition years and only to a small degree less so in more recent years research 
Table 7 Inventor Outflows-Part I

\begin{tabular}{|c|c|c|c|c|c|c|}
\hline & \multicolumn{3}{|l|}{ Lag-Model } & \multicolumn{3}{|l|}{ Durbin-Model } \\
\hline & I & II & III & I & II & III \\
\hline LAGT-1 & $\begin{array}{l}0.1162 \\
(1.09)\end{array}$ & $\begin{array}{l}0.2963^{* * *} \\
(2.53)\end{array}$ & $\begin{array}{l}0.0774 \\
(0.42)\end{array}$ & $\begin{array}{l}0.1137 \\
(1.06)\end{array}$ & $\begin{array}{l}0.2987 * * \\
(2.55)\end{array}$ & $\begin{array}{l}0.0636 \\
(0.33)\end{array}$ \\
\hline RES & $\begin{array}{l}0.5337 * * * \\
(4.04)\end{array}$ & $\begin{array}{l}0.7316^{* * * *} \\
(17.69)\end{array}$ & $\begin{array}{l}0.7978 * * * \\
(15.41)\end{array}$ & $\begin{array}{l}0.5438 * * * \\
(4.07)\end{array}$ & $\begin{array}{l}0.7505^{* * *} \\
(17.40)\end{array}$ & $\begin{array}{l}0.8117^{* * * *} \\
(14.95)\end{array}$ \\
\hline GRPPC & $\begin{array}{l}-15.9000 * * \\
(-2.36)\end{array}$ & $\begin{array}{l}-52.4000 * * * \\
(-3.16)\end{array}$ & $\begin{array}{l}-14.0000^{* * * *} \\
(-4.20)\end{array}$ & $\begin{array}{l}-11.9000 \\
(-1.61)\end{array}$ & $\begin{array}{l}-54.0000 * * \\
(-2.42)\end{array}$ & $\begin{array}{l}-13.0000 \text { *** } \\
(-2.85)\end{array}$ \\
\hline PATSTO & $\begin{array}{l}-0.1752 \text { *** } \\
(-11.07)\end{array}$ & $\begin{array}{l}-0.0631 * * * \\
(-3.60)\end{array}$ & $\begin{array}{l}-0.1079 * * * \\
(-7.45)\end{array}$ & $\begin{array}{l}-0.1754 * * * \\
(-11.01)\end{array}$ & $\begin{array}{l}-0.0679 * * * \\
(-3.74)\end{array}$ & $\begin{array}{l}-0.1095^{* * * *} \\
(-7.25)\end{array}$ \\
\hline SME & $\begin{array}{l}-1.0703 \\
(-0.62)\end{array}$ & $\begin{array}{l}-0.9483 \\
(-1.16)\end{array}$ & $\begin{array}{l}-1.3522 * \\
(-1.86)\end{array}$ & $\begin{array}{l}-0.5802 \\
(-0.33)\end{array}$ & $\begin{array}{l}-0.5886 \\
(-0.66)\end{array}$ & $\begin{array}{l}-0.9054 \\
(-1.16)\end{array}$ \\
\hline TRDUM & $\begin{array}{l}-0.4691 \\
(-1.28)\end{array}$ & & & $\begin{array}{l}-0.0884 \\
(-0.15)\end{array}$ & & \\
\hline$\lambda$ & $\begin{array}{l}-0.2989 \\
(-0.91)\end{array}$ & $\begin{array}{l}0.0367 \\
(0.19)\end{array}$ & $\begin{array}{l}-0.0932 \\
(-0.46)\end{array}$ & & & \\
\hline$\lambda \mathrm{RES}$ & & & & $\begin{array}{l}1.2985 \\
(0.89)\end{array}$ & $\begin{array}{l}0.3153 \\
(0.66)\end{array}$ & $\begin{array}{l}-0.9356 \\
(-1.22)\end{array}$ \\
\hline$\lambda \mathrm{GRPPC}$ & & & & $\begin{array}{l}-16.5000 \\
(-1.39)\end{array}$ & $\begin{array}{l}-2.8400 \\
(-0.07)\end{array}$ & $\begin{array}{l}-19.0000 * * \\
(-2.07)\end{array}$ \\
\hline$\lambda$ PATSTO & & & & $\begin{array}{l}0.2936 \\
(1.21)\end{array}$ & $\begin{array}{l}0.0344 \\
(0.16)\end{array}$ & $\begin{array}{l}0.4141 \\
(1.66)\end{array}$ \\
\hline$\lambda \mathrm{SME}$ & & & & $\begin{array}{l}-8.5583 \\
(-1.34)\end{array}$ & $\begin{array}{l}-5.1278 \\
(-1.16)\end{array}$ & $\begin{array}{l}2.4061 \\
(0.48)\end{array}$ \\
\hline CONST & $\begin{array}{l}2.0881 * * \\
(2.17)\end{array}$ & $\begin{array}{l}-0.0240 \\
(-0.20)\end{array}$ & $\begin{array}{l}-0.0444 \\
(-0.33)\end{array}$ & $\begin{array}{l}-2.2733 \\
(-0.39)\end{array}$ & $\begin{array}{l}0.0105 \\
(0.09)\end{array}$ & $\begin{array}{l}0.0120 \\
(0.09)\end{array}$ \\
\hline $\operatorname{Adj} . R^{2}$ & 0.388 & 0.732 & 0.666 & 0.389 & 0.731 & 0.674 \\
\hline F Test & $65.883^{* * *}$ & $327.330 * * *$ & $239.604 * * *$ & $46.661 * * *$ & $217.808 * * *$ & $165.827 * * *$ \\
\hline
\end{tabular}

in the Russian Federation is clustered in just a few regions. If inventors mostly switched between these regions then they would leave a region with a wellestablished research structure to locate into one with a well-established structure as well.

This assumption is furthermore strengthened by the consistently positive effect of the lagged dependent variable showing that inventor flows especially in the transition years have been path-dependent. What is speaking against this hypothesis is as discussed in more length in (Perret, 2013) that inventor mobility mostly occurs from the outlying regions to Moscow, St. Petersburg or the Moscow area and only in rare cases the other way round. However, including Novosibirsk and some regions close to Moscow or St. Petersburg this already encompasses most of the significant research centers and thus can explain the observed effects. 
Table 8 Inventor Outflows-Part II

\begin{tabular}{|c|c|c|c|c|c|c|}
\hline & \multicolumn{3}{|l|}{ Lag-Model } & \multicolumn{3}{|l|}{ Durbin-Model } \\
\hline & I & II & III & I & II & III \\
\hline LAGT-1 & $\begin{array}{l}0.2652 * * * \\
(2.72)\end{array}$ & $\begin{array}{l}0.2092 \\
(1.35)\end{array}$ & $\begin{array}{l}0.1891 \\
(1.04)\end{array}$ & $\begin{array}{l}1.1468 * * * \\
(4.16)\end{array}$ & $\begin{array}{l}0.4873 * * \\
(2.33)\end{array}$ & $\begin{array}{l}0.1593 \\
(0.88)\end{array}$ \\
\hline RES & $\begin{array}{l}0.8279 * * * \\
(5.08)\end{array}$ & $\begin{array}{l}0.4033 * * * \\
(7.66)\end{array}$ & $\begin{array}{l}0.7970 * * * \\
(15.90)\end{array}$ & $\begin{array}{l}0.4351 * * * \\
(4.08)\end{array}$ & $\begin{array}{l}0.3667 * * * \\
(5.16)\end{array}$ & $\begin{array}{l}0.8423 \text { *** } \\
(16.42)\end{array}$ \\
\hline GRPPC & $\begin{array}{l}-9.5800 \\
(-1.26)\end{array}$ & $\begin{array}{l}0.0220 \\
(1.50)\end{array}$ & $\begin{array}{l}10.7000 * * \\
(2.53)\end{array}$ & $\begin{array}{l}-18.2000 \\
(-0.67)\end{array}$ & $\begin{array}{l}46.6000 * \\
(1.82)\end{array}$ & $\begin{array}{l}5.8300 \\
(0.90)\end{array}$ \\
\hline PATSTO & $\begin{array}{l}0.0004 \\
(0.01)\end{array}$ & $\begin{array}{l}0.0221 \\
(1.27)\end{array}$ & $\begin{array}{l}0.0827 * * * \\
(4.28)\end{array}$ & $\begin{array}{l}0.4982^{* * * *} \\
(10.14)\end{array}$ & $\begin{array}{l}0.0228 \\
(0.91)\end{array}$ & $\begin{array}{l}0.0733 * * * \\
(3.72)\end{array}$ \\
\hline SME & $\begin{array}{l}-0.6110 \\
(-0.35)\end{array}$ & $\begin{array}{l}-0.6814 \\
(-0.99)\end{array}$ & $\begin{array}{l}2.2980 * * * \\
(2.95)\end{array}$ & $\begin{array}{l}-1.6516 \\
(-0.89)\end{array}$ & $\begin{array}{l}-1.2202 \\
(-1.21)\end{array}$ & $\begin{array}{l}2.2824 * * * \\
(2.95)\end{array}$ \\
\hline EX & $\begin{array}{l}-0.0078 * * * \\
(-7.97)\end{array}$ & $\begin{array}{l}-0.0045^{* * * *} \\
(-8.82)\end{array}$ & $\begin{array}{l}-0.0004 \\
(-0.60)\end{array}$ & $\begin{array}{l}-0.0035^{* * * *} \\
(-2.95)\end{array}$ & $\begin{array}{l}-0.0061^{* * *} \\
(-7.48)\end{array}$ & $\begin{array}{l}0.0007 \\
(0.85)\end{array}$ \\
\hline IM & $\begin{array}{l}0.0062 * * * \\
(8.78)\end{array}$ & $\begin{array}{l}0.0064 * * * \\
(13.81)\end{array}$ & $\begin{array}{l}-0.0422 * * * \\
(-11.66)\end{array}$ & $\begin{array}{l}0.0084^{* * * *} \\
(11.50)\end{array}$ & $\begin{array}{l}0.0083^{* * * *} \\
(14.01)\end{array}$ & $\begin{array}{l}-0.0442 \text { *** } \\
(-11.27)\end{array}$ \\
\hline OPEN & $\begin{array}{l}0.0004 \\
(0.10)\end{array}$ & $\begin{array}{l}-0.0036 \\
(-1.28)\end{array}$ & $\begin{array}{l}0.1881^{* *} \\
(2.37)\end{array}$ & $\begin{array}{l}-0.0017 \\
(-0.44)\end{array}$ & $\begin{array}{l}-0.0022 \\
(-0.40)\end{array}$ & $\begin{array}{l}0.2698 * * * \\
(3.07)\end{array}$ \\
\hline FDI & $\begin{array}{l}0.0119 * * * \\
(6.90)\end{array}$ & $\begin{array}{l}0.0102 * * * \\
(9.67)\end{array}$ & $\begin{array}{l}-0.0037 \\
(-1.46)\end{array}$ & $\begin{array}{l}0.0121 * * * \\
(8.37)\end{array}$ & $\begin{array}{l}0.0113 * * * \\
(9.79)\end{array}$ & $\begin{array}{l}-0.0027 \\
(-1.05)\end{array}$ \\
\hline STUD & $\begin{array}{l}-0.0680 \text { *** } \\
(-6.53)\end{array}$ & $\begin{array}{l}-0.0070 \\
(-0.69)\end{array}$ & $\begin{array}{l}-0.0356 * * * \\
(-7.77)\end{array}$ & $\begin{array}{l}-0.1267 * * * \\
(-7.71)\end{array}$ & $\begin{array}{l}0.0037 \\
(0.26)\end{array}$ & $\begin{array}{l}-0.0359 * * * \\
(-6.87)\end{array}$ \\
\hline SHADOW & $\begin{array}{l}0.0046 \\
(0.26)\end{array}$ & $\begin{array}{l}-0.0043 \\
(-0.59)\end{array}$ & $\begin{array}{l}0.0043 \\
(0.61)\end{array}$ & $\begin{array}{l}-0.0020 \\
(-0.09)\end{array}$ & $\begin{array}{l}0.0129 \\
(0.93)\end{array}$ & $\begin{array}{l}0.0058 \\
(0.70)\end{array}$ \\
\hline TRDUM & $\begin{array}{l}-1.0884 * * * \\
(-2.75)\end{array}$ & & & $\begin{array}{l}-0.8125 \\
(-0.63)\end{array}$ & & \\
\hline$\lambda$ & $\begin{array}{l}-0.6396^{*} \\
(-1.93)\end{array}$ & $\begin{array}{l}0.0362 \\
(0.19)\end{array}$ & $\begin{array}{l}-0.3822 \\
(-1.62)\end{array}$ & & & \\
\hline$\lambda \mathrm{RES}$ & & & & $\begin{array}{l}-3.0126 \\
(-0.97)\end{array}$ & $\begin{array}{l}2.9784 * \\
(1.80)\end{array}$ & $\begin{array}{l}-2.8621^{*} \\
(-1.71)\end{array}$ \\
\hline$\lambda \mathrm{GRPPC}$ & & & & $\begin{array}{c}244.6000 \\
(1.23)\end{array}$ & $\begin{array}{l}-45.3000 \\
(-0.38)\end{array}$ & $\begin{array}{l}-8.9800 \\
(-0.17)\end{array}$ \\
\hline גPATSTO & & & & $\begin{array}{l}-0.5163 \\
(-0.72)\end{array}$ & $\begin{array}{l}-0.8035 \\
(-1.18)\end{array}$ & $\begin{array}{l}1.8318^{*} \\
(1.96)\end{array}$ \\
\hline$\lambda \mathrm{SME}$ & & & & $\begin{array}{l}-6.4520 \\
(-0.54)\end{array}$ & $\begin{array}{l}-16.0919 \\
(-1.19)\end{array}$ & $\begin{array}{l}22.0261 \\
(1.21)\end{array}$ \\
\hline$\lambda \mathrm{EX}$ & & & & $\begin{array}{l}-0.0111 \\
-0.81)\end{array}$ & $\begin{array}{l}-0.0354 \\
(-2.20)\end{array}$ & $\begin{array}{l}0.0655^{* * * *} \\
(3.18)\end{array}$ \\
\hline$\lambda \mathrm{IM}$ & & & & $\begin{array}{l}-0.0021 \\
(-0.21)\end{array}$ & $\begin{array}{l}-0.0076 \\
(-0.67)\end{array}$ & $\begin{array}{l}-0.1964 \\
(-1.62)\end{array}$ \\
\hline$\lambda \mathrm{OPEN}$ & & & & $\begin{array}{l}0.0727 \\
(1.17)\end{array}$ & $\begin{array}{l}0.2014 * * \\
(2.41)\end{array}$ & $\begin{array}{l}-5.1345^{* *} \\
(-2.15)\end{array}$ \\
\hline$\lambda \mathrm{FDI}$ & & & & 0.0080 & $0.0437 * *$ & 0.0633 \\
\hline
\end{tabular}


Table 8 (continued)

\begin{tabular}{|c|c|c|c|c|c|c|}
\hline & \multicolumn{3}{|l|}{ Lag-Model } & \multicolumn{3}{|l|}{ Durbin-Model } \\
\hline & I & II & III & I & II & III \\
\hline & & & & $(0.39)$ & $(2.38)$ & $(0.65)$ \\
\hline \multirow[t]{2}{*}{$\lambda$ STUD } & & & & 0.0279 & -0.1055 & $-0.2035^{*}$ \\
\hline & & & & $(0.27)$ & $(-0.58)$ & $(-1.90)$ \\
\hline \multirow[t]{2}{*}{$\lambda$ SHADOW } & & & & 0.0488 & 0.1259 & 0.1829 \\
\hline & & & & $(0.35)$ & $(0.79)$ & $(1.35)$ \\
\hline \multirow[t]{2}{*}{ CONST } & $2.4859 * *$ & -0.0158 & 0.0204 & -3.8092 & 0.0316 & 0.0013 \\
\hline & $(2.15)$ & $(-0.16)$ & $(0.18)$ & $(-0.91)$ & $(0.31)$ & $(0.01)$ \\
\hline $\operatorname{Adj} . \mathrm{R}^{2}$ & 0.415 & 0.849 & 0.724 & 0.253 & 0.718 & 0.737 \\
\hline F Test & $40.211 * * *$ & $331.501 * * *$ & $158.011 * * *$ & $12.033 * * *$ & $88.050 * * *$ & $97.040 * * *$ \\
\hline
\end{tabular}

As inventor outflows are the mirror image of inventor inflows consequently the impacts of gross regional product per capita on inventor outflows are as would be expected underlining the argument from above that rent-seeking is an important motive for inventors to search for employment in another region. As the sign in this case is positive-except in the case without control variables-independent of the period observed it can also be that inventors actually had to be in rich regions to become important inventors and then move to other well-off regions.

There can be a number of reasons for the ambiguous sign of the patent stock. Nevertheless, looking ahead to the results in the next part of the analysis, and considering that the results of the enlarged model can be considered more stable, a positive impact of the patent stock that is also more in line with previous arguments seems to be more reasonable. This leads to the assumption that in the Russian Federation a higher patent stock, which also can be seen as an indicator of the regional science system, has a positive impact on inventor inflows as well as inventor outflows.

When summarizing the regression results the outcomes for the inflow and the outflow of inventors are for the most part in line with each other. The patent stock shows a consistently positive effect while the GRP per capita reports either a positive or an insignificant sign. This shows that what attracts researchers also leads to researchers leaving the region. The conclusion to be drawn from these results is that a well-established research base that allows for income gains and in particular in the later years in not dominated by large companies alone but sports a large share of small and medium enterprises as well will in general be more beneficial for inventor mobility and thus the diffusion of knowledge.

Taking into account that the inventor movements-inflows as well as outflowsare by design a positive discrete variable the use of a Poisson or a negative binomial estimator might be more suitable than a linear estimation approach. Furthermore, taking a look at the figures of the inventor movements shown in a previous section it becomes clear that a large amount of zero observations is present distorting the regression results. 
These arguments have been taken into account and the distribution of both variables_-inflows and outflows - has been plotted against a Poisson and a negative binomial distribution with the same mean or the same mean and same variance, respectively. This test clearly indicates that the variable's distribution more closely follows a negative binomial distribution than a Poisson distribution. Therefore, only the negative binomial model has been considered further.

Accounting for the large amount of zeros in the variables leads to a zero-inflated negative binomial model which is shown to be a prudent choice by the conducted Vuong tests. However, missing a suitable estimation procedure that accounts for zero inflation and fits a negative binomial model, while at the same time accounting for spatial and serial autocorrelation and the panel structure of the available data sets, the following analysis is restricted to a simple zero-inflated negative binomial model using pooled data. ${ }^{19}$

Table 9 reports the regression results for both variables. It is divided into two parts with the first part reporting the results for the negative binomial regression-estimating the amount of flows taking place-and the second part reporting the results for the logit process - as the zero generating process. Thus, the second part reports in how far the chance of an inventor movement to take place in the first place is impacted, while the first part describes what impacts the size of the inventor movement.

The last row of the table reports the Vuong test scores. The Vuong test checks whether a zero-inflated model is more fitting in the respective case than a noninflated model. It can be clearly seen that in all cases the test indicates with a very high significance level that the zero-inflated model is superior to the respective noninflated model.

The results are mostly in line with the previous results. However, with a view to the stock of patents, the results are more consistent. For both flows the stock of patents reports a significantly positive impact in the transition years. In the later years the impact becomes negative, but it is highly insignificant. This leads to the conclusion that regions with a high amount of past patents have been more prone to attract inventors as well as serve as a provider of inventors that move to other regions.

Considering the logit process the patent stock has a consistently negative impact. This can be interpreted that a number of regions have past patents; however, inventors are less prone to move to these regions or leave them. While at first it might seem counter-intuitive in conjunction with the results for the negative binomial process, however there are some regions that during Soviet times had a well-established research infrastructure which in the course of the transition became defunct leading to an effect that can be described by the results from the logit process. The results from the negative binomial represent those regions that had a research infrastructure

\footnotetext{
19 Practically this omission is not that large of a problem as the results of the Spatial Lag Han-Philips Linear Dynamic Panel Data Regression and the Spatial Durbin Han-Philips Linear Dynamic Panel Data Regression showed that spatial effects are almost negligible and even the time lagged variable is only significant in some select situations.
} 
Table 9 Zero-Inflated Negative Binominal Regression

\begin{tabular}{|c|c|c|c|c|c|c|}
\hline & \multicolumn{3}{|c|}{ Inventor Inflows } & \multicolumn{3}{|c|}{ Inventor Outflows } \\
\hline & I & II & III & I & II & III \\
\hline & \multicolumn{6}{|c|}{ Negative Binominal } \\
\hline \multirow[t]{2}{*}{ RES } & $0.0741 * * *$ & $0.0432 * * *$ & 0.113 & $0.0822 * * *$ & $0.0489 * * *$ & $0.0586^{*}$ \\
\hline & $(3.59)$ & $(3.06)$ & $(1.25)$ & $(3.64)$ & $(4.00)$ & $(1.65)$ \\
\hline \multirow[t]{2}{*}{ GRPPC } & 0.3080 & 1.3600 & -0.6470 & 0.3540 & -0.5550 & -1.1700 \\
\hline & $(0.61)$ & $(0.76)$ & $(-0.44)$ & $(0.44)$ & $(-0.24)$ & $(-1.00)$ \\
\hline \multirow[t]{2}{*}{ PATSTO } & -0.0041 & $0.0171 * *$ & -0.0142 & -0.0095 & $0.0111 * *$ & -0.0107 \\
\hline & $(-0.54)$ & $(2.26)$ & $(-0.90)$ & $(-1.21)$ & $(2.14)$ & $(-0.88)$ \\
\hline \multirow[t]{2}{*}{ SME } & -0.6449 & 0.9649 & -0.2825 & $-1.8006^{* * * *}$ & $-2.2941 * * *$ & -0.1479 \\
\hline & $(-0.44)$ & $(0.95)$ & $(-0.19)$ & $(-4.93)$ & $(-3.52)$ & $(-)$ \\
\hline \multirow[t]{2}{*}{ EX } & $-0.1207 * * *$ & $-0.1155 * * *$ & -0.0117 & $-0.1157 * * *$ & $-0.1248 * * *$ & -0.0282 \\
\hline & $(-4.37)$ & $(-4.65)$ & $(-0.06)$ & $(-6.30)$ & $(-5.65)$ & $(-0.44)$ \\
\hline \multirow[t]{2}{*}{ IM } & 0.0312 & 0.0233 & 0.1908 & 0.0278 & 0.0371 & 0.2477 \\
\hline & (1.33) & $(0.75)$ & $(0.71)$ & $(1.42)$ & $(1.25)$ & (1.04) \\
\hline \multirow[t]{2}{*}{ OPEN } & $0.0139^{*}$ & $0.0216 * * *$ & -0.2109 & $0.0118^{*}$ & $0.0134 * *$ & -0.3044 \\
\hline & $(1.65)$ & $(2.73)$ & $(-1.04)$ & $(1.84)$ & $(2.22)$ & $(-1.57)$ \\
\hline \multirow[t]{2}{*}{ FDI } & 0.0768 & -0.0108 & -0.3638 & $0.1068 * * *$ & 0.0399 & -0.0245 \\
\hline & $(1.51)$ & $(-0.14)$ & $(-0.56)$ & $(3.20)$ & $(0.66)$ & $(-0.18)$ \\
\hline \multirow[t]{2}{*}{ STUD } & -0.0014 & -0.0019 & -0.0020 & -0.0007 & -0.0016 & -0.0004 \\
\hline & $(-0.62)$ & $(-0.44)$ & $(-0.18)$ & $(-0.24)$ & $(-0.51)$ & $(-0.09)$ \\
\hline \multirow[t]{2}{*}{ SHADOW } & 0.0022 & -0.0108 & -0.0214 & $0.0196 * * *$ & 0.0045 & 0.0031 \\
\hline & $(0.31)$ & $(-0.94)$ & $(-0.55)$ & $(2.97)$ & $(0.49)$ & $(0.29)$ \\
\hline \multirow[t]{2}{*}{ TRDUM } & -0.4604 & & & -0.4503 & & \\
\hline & $(-1.42)$ & & & $(-1.41)$ & & \\
\hline \multirow[t]{3}{*}{ CONST } & 0.3723 & -0.6226 & 1.7954 & -0.1625 & 0.5360 & 1.7757 \\
\hline & $(0.53)$ & $(-0.77)$ & $(0.73)$ & $(-0.22)$ & $(0.86)$ & (1.28) \\
\hline & Logit & & & & & \\
\hline \multirow[t]{2}{*}{ RES } & -0.0682 & $-2.8786^{* * * *}$ & -0.0237 & -0.2766 & $-0.8556^{* *}$ & 0.0555 \\
\hline & $(-0.51)$ & $(-2.20)$ & $(-0.07)$ & (1.03) & $(-2.12)$ & $(0.29)$ \\
\hline \multirow[t]{2}{*}{ GRPPC } & 2.4300 & 3.4400 & 3.7300 & 2.9300 & -0.997 & 1.3300 \\
\hline & $(1.45)$ & $(0.44)$ & $(0.32)$ & $(1.05)$ & $(-0.20)$ & (1.04) \\
\hline \multirow[t]{2}{*}{ PATSTO } & $-0.6366 * * *$ & $-3.9775^{* *}$ & -0.7532 & $-0.4508^{*}$ & -0.2425 & $-0.8005^{* * *}$ \\
\hline & $(-2.82)$ & $(-2.24)$ & $(-0.55)$ & $(-1.82)$ & $(-1.33)$ & $(-3.66)$ \\
\hline \multirow[t]{2}{*}{ SME } & 0.6715 & $18.1148 * * *$ & -0.0268 & -6.5273 & $-7.9701^{*}$ & -0.4758 \\
\hline & $(0.37)$ & $(2.81)$ & $(-)$ & $(-)$ & $(-1.66)$ & $(-0.36)$ \\
\hline \multirow[t]{2}{*}{ EX } & $-0.4624 * * *$ & $-1.3583 * * *$ & -0.4815 & $-0.5428 * * *$ & $-0.5611^{* *}$ & $-0.7412 * *$ \\
\hline & $(-2.69)$ & $(-2.68)$ & $(-0.73)$ & $(-4.49)$ & $(-2.43)$ & $(-2.13)$ \\
\hline \multirow[t]{2}{*}{ IM } & 0.4333 & $5.6885^{* *}$ & -4.2875 & -0.3337 & -0.1976 & $3.6079 * * *$ \\
\hline & $(1.54)$ & $(2.31)$ & $(-0.27)$ & $(-1.46)$ & $(-0.85)$ & $(2.85)$ \\
\hline \multirow[t]{2}{*}{ OPEN } & 0.0260 & -0.0088 & 0.0191 & $0.0435 * * *$ & 0.0201 & -0.3216 \\
\hline & (1.34) & $(-0.18)$ & $(0.03)$ & $(2.83)$ & (1.44) & $(-1.59)$ \\
\hline FDI & 0.1664 & $3.0683^{*}$ & -0.2083 & 1.3929 & $3.4311 * *$ & 0.4260 \\
\hline
\end{tabular}


Table 9 (continued)

\begin{tabular}{|c|c|c|c|c|c|c|}
\hline & \multicolumn{3}{|c|}{ Inventor Inflows } & \multicolumn{3}{|c|}{ Inventor Outflows } \\
\hline & I & II & III & I & II & III \\
\hline & $(0.31)$ & $(1.67)$ & $(-0.15)$ & $(1.29)$ & $(2.17)$ & $(0.51)$ \\
\hline STUD & $\begin{array}{l}-0.0081 \\
(-0.60)\end{array}$ & $\begin{array}{l}-0.1500 * \\
(-1.72)\end{array}$ & $\begin{array}{l}-0.0070 \\
(-0.08)\end{array}$ & $\begin{array}{l}0.0077 \\
(0.22)\end{array}$ & $\begin{array}{l}-0.1246^{* * *} \\
(-2.14)\end{array}$ & $\begin{array}{l}0.0259 \\
(1.87)\end{array}$ \\
\hline SHADOW & $\begin{array}{l}0.0144 \\
(1.49)\end{array}$ & $\begin{array}{l}-0.0532 \\
(-1.63)\end{array}$ & $\begin{array}{l}-0.0004 \\
(-0.01)\end{array}$ & $\begin{array}{l}0.0284 \\
(1.23)\end{array}$ & $\begin{array}{l}0.0284 \\
(1.27)\end{array}$ & $\begin{array}{l}0.0130 \\
(0.69)\end{array}$ \\
\hline TRDUM & $\begin{array}{l}-0.3106 \\
(-0.52)\end{array}$ & & & $\begin{array}{l}-0.4523 \\
(-0.64)\end{array}$ & & \\
\hline CONST & $\begin{array}{l}1.6678^{* * *} \\
(1.99)\end{array}$ & $\begin{array}{l}7.7674 \\
(1.64)\end{array}$ & $\begin{array}{l}2.2687 \\
(0.54)\end{array}$ & $\begin{array}{l}2.9765^{* * * *} \\
(3.40)\end{array}$ & $\begin{array}{l}7.2778^{* * *} \\
(2.20)\end{array}$ & $\begin{array}{l}2.5135^{* *} \\
(2.50)\end{array}$ \\
\hline$\chi^{2}$ & 217.27 & 685.95 & 130.52 & 368.45 & $1 \mathrm{k}$ & - \\
\hline Vuong & $5.22 * * *$ & $4.89 * * *$ & $2.56 * * *$ & $6.52 * * *$ & $5.40 * * *$ & $4.23 * * *$ \\
\hline
\end{tabular}

and managed to keep it going during transition as has been the case for example in Novosibirsk.

Furthermore, it is interesting to note that the exports have a consistently negative effect while the effect of the regional openness is positive-especially during the transition years. This might be an indicator that export oriented firms are comparatively less focused on innovations, and are thus less interesting for inventors to start working with, and they also produce less inventors themselves. This is quite reasonable since the Russian export sector is dominated by natural resources, a sector which especially during the transition years has been only marginally innovative and the negative effects of exports are thus most pronounced during the transition years. Considering that Russian exports are mainly resource-based a negative also implies indirectly that knowledge in the regional economic setup might not play that important a role. As the sign is consistently negative and in almost all cases significant it thus illustrates that the RF on average has been primarily a resource-driven economy.

Finally, for the later years the results for the negative binomial are almost consistently insignificant showing that the inventor flows during these times cannot be sufficiently described by using the implemented variables. The single most significant variable in both cases is the researcher variable showing that the size of the available research system still is the single most important aspect for the inflow and the outflow of inventors. Nevertheless, for the inflow of inventors the variable is still insignificant. This can also be an indicator that instead of moving to another Russian region Russian inventors rather prefer to move abroad. To check for these movements, however, other data sources than the patents granted by the European Patent Office need to be studied. 


\section{Conclusions}

\section{Summary of the Results}

Summarizing the results from the estimations conducted in the previous section, it can be seen that the number of researcher is the only variable that exudes a consistently positive and significant impact. While GRP p.c., the patent stock and the share of small and medium enterprises are significant in some models no consistently coherent pattern can be made out for them. Even though, the main trend points to a mostly positive effect of GRP p.c.

If only those models are considered that incorporate the full set of variables including the controls. A partly coherent structure emerges as the stock of patents reports a positive effect. GRP p.c. and the share of SMEs still remain inconclusive.

Spatial effects via the dependent variable as well as via the independents remain almost exclusively insignificant across all model variants making the presence of inter-regional effects in the context of inventor flows highly unlikely.

It is thus primarily the research-based variables that drive inventor flows. Inventors come from knowledge-rich regions and are drawn to knowledge-rich regions.

\section{Discussion}

Aside from reducing general barriers of free labor movement across the regions of the RF, this study finds that in particular a long-term-oriented rise in income levels might be a benefactor to increased inventor mobility and thus increased knowledge diffusion.

Furthermore, for both types of inventor mobility a better established science and technology system inside a region, as measured by a higher amount of researchers and a larger patent stock, generally seems to have a positive effect on the attraction of active inventors - it has been so especially in the transition years-and can therefore be seen as an investment in a more sustainable innovation system and through knowledge effects on growth ${ }^{20}$, to be more beneficial for long-run growth. In addition, the current size of the innovation system seems to have the most significant effect. This does not mean that a region with a developed innovation system should not rest on its past standing, but needs to constantly invest in it, or else highly innovative researchers might still leave the region. This, however, would imply that the RF needs to focus even more strongly on establishing a science-based industrial complex and the corresponding academic backbone to generate new researchers. In particular the increase of a research-oriented industry might as well lead to rising GRP and thus GRP per capita levels thus making regions double as interesting for potential inventors.

The generally positive impact of GRP per capita on inventor inflows and inventor outflows-less pronounced in the later years-shows that inventors in the RF might

${ }^{20}$ See in this regard in particular (Perret, 2014). 
be actively following rent-seeking motives. This line of argumentation is strengthened at least somewhat by the fact that in the years after the collapse of the Soviet Union a number of qualified workers moved from the remote Northern and Eastern parts of Russia towards the central parts thus initiating a movement of tacit knowledge- one of the reason for which might be found besides better living conditions in relatively higher earning possibilities. This movement decreased in the $2000 \mathrm{~s}$ incidentally the same period where a decrease is found in this study of the effect of GRP. A second explanation might be found in the overall increase in household incomes in the 2000s due to a more favorable economic climate coming hand in hand with an increase in oil prices. For policymakers that can be seen as a sign that if the brain-drain, affecting not only the RF as a whole, but peripheral regions of the Federation in specific, is to be stopped the first thing to do would be to guarantee qualified researchers and inventors income possibilities that are comparable to those of other countries or from an RF centered point of view at least comparable to income possibilities in central regions close to Moscow.

A research-based industrial development and modernization of peripheral regions is therefore the only perceived chance to stop a convergence process of the Russian innovation system to a state where it is limited to only a handful of highly developed regions - first and foremost the larger Moscow area.

Finally, the inconclusiveness of the share of SMEs could be an indication that, independent of the type of knowledge flow considered, the presence of more and larger firms had been more beneficial than the presence of more small and medium firms in the past, but their importance has degraded in later years. As this study stops short of 2008 current developments have not been considered which might turn the tide back to large companies as the primary driver of knowledge diffusion.

Thus, the potential insignificance of the share of SME considering inventor inflows should not be taken as an indicator that promotion of SME should be reduced and subventions should go solely to large firms. On the contrary, the results show that the SME in the RF might still have the potential to become the vital actors in the Russian NIS they already are in Western economies ${ }^{21}$. Incidentally, in recent times (as of 2021) the economic downturn of the Russian economy is seeing an increase in entrepreneurs even though very few of them get to take the step towards successfully establishing a medium-sized enterprise. Thus, due to suffering from corrupt practices and a faulty rule of law incentives to grow business are rather small. Additional corruption control aside from leading to an overall better business climate would therefore in particular be beneficial for the growth of small companies which then might increase knowledge generation and diffusion.

The foundation of institutions of knowledge transfer that have already been mentioned above: techno parks, research and technology information centers, centers for technology transfer and centers for joined enterprises, is therefore a prudent choice for Russian research policy. While the effect of establishing an institution like this is not studied in detail herein, (Perret, 2013) links the establishment of these institu-

$\overline{{ }^{21} \text { See (Acs \& Audretsch, 1988) }}$ (Acs et al., 1994) or (Ayyagari et al., 2003). 
tions to an increase in the knowledge generation and thus growth of a research infrastructure which by itself is beneficial to inventor movements.

Aside from the motivated indirect effects these institutions also have a direct effect as they strengthen the regional innovation systems and help to promote the role of SME in the context of the Russian NIS. The same holds true for national research funds like the RFTD (Russian Fund for Technological Development) and institutions like the FASIE (Foundation for Assistance to Innovative Enterprises) or the Russian Venture Company.

Summarizing the results of this study, Russian policymaker should focus on the following aspects in particular:

- Offer competitive incomes in research (outside the larger Moscow and St. Petersburg area) to attract researchers to peripheral regions. Realize incentives for companies to offer competitive incomes or other monetary incentives.

- Extend the promotion of those instruments of science and technology policy that strengthen and develop the Russian NIS as well as the overall economic development.

- Foster the foundation of SMEs for them to realize the potential they have in Western economies. Abolish current corrupt practices allowing SMEs to grow into innovative medium-sized enterprises.

- Foster the foundation and maintenance of institutions of knowledge transfer.

- Actively foster structural change, in domestic production as well as exports, away from resource extraction to knowledge intensive sectors.

\section{Outlook}

Having used tools from network analysis, knowledge flows across the regions of the RF based on inventor mobility via patents from the European Patent Office are measured. The succeeding analysis deduced key drivers of the inventor movements showing that it is first and foremost the absolute size of the regional research system, its history with developing internationally relevant patents and the average standard of living in a region that drive inventors to move to these regions but also to leave them again.

While this study presents an essential aspect of the Russian national innovation system to get a deeper understanding of the functionality of the whole system, its dynamics and links with other systems many additional studies are still needed. Part of these additional studies could focus on in how far institutions of knowledge transfer directly impact the knowledge diffusion process. Here a more case study oriented analysis seems to be prudent.

Furthermore, this study bases itself on only a select number of patents for analyzing the inventor movements, particularly those from the period 1992 to 2008 issued by the European Patent Office. This perspective can be extended by including more recent EPO patent data. This would also allow to study the effects of the economic crisis of 2008 and the effects of the economic sanctions levied on the RF in the aftermath of the occupation of Crimea in 2014. It would furthermore allow for a 
study on how innovation policy in the RF differed effectively across the corresponding presidencies. Including data not only from the EPO, but also from Rospatent would allow to studying differences between the outwards bound innovation system and the domestically oriented innovation system. That the two behave significantly different has been shown already in (Perret, 2017). While both data sources have some limitations they can still help in creating a more complete picture of the Russian national innovation system and in particular shed some light on links between the national and the international oriented innovation system.

Using national Rospatent data would also help to use a broader database and thus generate a much denser network which could be divided into different industries or regions offering policymakers a more in-depths look as well into the workings of the different regional innovation systems. Considering the inventor network as such a broader base would allow to better illustrate career paths of inventors over time and establish whether the assumption issued above that a consistent movement of inventors towards the larger Moscow area or other growth poles takes place.

Picking up the hypothesis issued in the course of the descriptive part of the analysis, it might be worthwhile to conduct comparable studies for other transition countries like China, Brazil or South Africa and evaluate whether patterns as witnessed here or in the study by (Alnuaimi et al., 2012) are repeated by these countries as well.

Acknowledgements The author is grateful to Evgeniya Yushkova, David Hanrahan and William Anderson for comments and technical support as well as to the unknown reviewers that provided valuable input.

Funding Open Access funding enabled and organized by Projekt DEAL.

Open Access This article is licensed under a Creative Commons Attribution 4.0 International License, which permits use, sharing, adaptation, distribution and reproduction in any medium or format, as long as you give appropriate credit to the original author(s) and the source, provide a link to the Creative Commons licence, and indicate if changes were made. The images or other third party material in this article are included in the article's Creative Commons licence, unless indicated otherwise in a credit line to the material. If material is not included in the article's Creative Commons licence and your intended use is not permitted by statutory regulation or exceeds the permitted use, you will need to obtain permission directly from the copyright holder. To view a copy of this licence, visit http://creativecommons.org/ licenses/by/4.0/.

\section{References}

Acs, Z., \& Audretsch, D. (1988). Innovation in large and small firms: An empirical analysis. The American Economics Review, 78, 678-690.

Acs, Z., Audretsch, D., \& Feldman, M. (1994). Randd spillovers and recipient firm size. Review of Economics and Statistics, 4, 336-340.

Alnuaimi, T., Opsahl, T., \& George, G. (2012). Innovating in the periphery: The impact of local and foreign inventor mobility on the value of Indian patents. Research Policy, 41, 1534-1543.

Andrienko, Y., \& Guriev, S. (2004). Determinants of interregional mobility in Russia. Economics of Transition, 12, 1-27.

Ayyagari, M., Beck, T., \& Demirgüç, A. (2003). Small and medium enterprises across the globe: A new database. Worldbank Policy Research Working Paper 3127.

Balconi, M., Breschi, S., \& Lissoni, F. (2004). Networks of inventors and the role of academia: An exploration of Italian patent data. Research Policy, 33, 127-145. 
Barber, M., \& Scherngell, T. (2011). Is the European R and D network homogeneous? Distinguishing relevant network communities using graph theoretic and spatial interaction modelling approaches. Regional Studies, 47, 1283-1298.

Breschi, S. \& Lissoni, F. (2003). Mobility and social networks: Local knowledge spillovers revisited. CESPRI Working Paper 142.

Breschi, S. \& Lissoni, F. (2004). Knowledge networks from patent data: Methodological issues and research targets. In W. Glanzel, H. Moed \& U. Schmoch, (Eds.) Handbook of Quantitative Science and Technology Research (1st ed., pp. 613-643). Springer, Berlin.

Breschi, S., \& Lissoni, F. (2009). Mobility of skilled workers and co-invention networks: An anatomy of localized knowledge flows. Journal of Economic Geography, 9, 439-468.

Cantner, U. (2006). The network of innovators in Jena: An application of social network analysis. Research Policy, 35, 463-480.

Chepurenko, A. (2015). The role of foreign scientific foundations' role in the cross-border mobility of Russian academics. International Journal of Manpower, 36, 562-584.

Coe, D., \& Helpman, E. (1993). International R and D spillovers. European Economic Review, 39, $859-887$.

Crespi, G., Geuna, A., \& Nesta, L. (2007). The mobility of university inventors in Europe. The Journal of Technology Transfer, 32, 195-215.

Deyun, Y., \& Kazuyuki, M. (2018). Inventor name disambiguation with gradient boosting decision tree and inventor mobility in China (1985-2016). RIETI Discussion Paper Series 18-E-018.

Dezhina, I. (2015). Intersectoral mobility of researchers in Russia: Trends and policy measures. Triple Helix, 2, 1-20.

Dyachenko, E. (2017). Internal migration of scientists in Russia and the USA: The case of physicists. Scientometrics, 113, 105-122.

Edler, J., Fier, H., \& Grimpe, C. (2008). International scientist mobility and the locus of technology transfer. ZEW Discussion Paper 08-082.

Emons, O. (2012). Innovation and Specialization Dynamics in the European Automotive Sector: Comparative Analysis of Cooperation and Application Network (1st ed., pp. 185-240). Heidelberg: Springer.

Erokhina, K. (2014). Scientists' social mobility and problems of its regulation by the state. Russian Education \& Society, 12, 9-23.

European Patent Office (2007). Patstat database. http://www.epo.org

Freeman, C. (1987). Technology Policy and Economic Performance: Lessons from Japan (1st ed.). London: Pinter.

Funk, M. F. (2001). International R and D spillovers and convergence among OECD countries. Journal of Economic Integration, 16, 48-65.

Hoisl, K. (2007). Tracing mobile inventors - the causality between inventor mobility and inventor productivity. Research Policy, 36, 619-636.

Indukaev, A., Mogoutov, A., \& Lepinay, V. (2014). Computer scientists from the former USSR: International mobility patterns and scientific success. Proceedings of the 10th Central and Eastern European Software Engineering Conference in Russia.

Ivankhnyuk, I. (2006). Brain drain from Russia: In search for a solution. Center for International Relations Reports \& Analyses 15/06.

Izquierdo, I., Vessuri, H., \& Gonzalez, R. (2018). Scientific collaboration networks of mathematicians from the former soviet union in the global south. Journal of Education and Human Development, 7, 83-93.

Jaffe, A., Trajtenberg, M., \& Henderson, R. (1993). Geographic localization of knowledge spillovers as evidenced by patent citations. The Quarterly Journal of Economics, 108, 577-598.

Johnson, S., Kaufmann, D., \& Shleifer, A. (1997). The unofficial economy in transition. Brookings Papers on Economic Activity, 2, 159-221.

Keller, W. (1998). Are international R and S spillovers trade-related? Analysing spillovers among randomly matched trade partners. European Economic Review, 42, 1469-1481.

Kosyakov, D., \& Guskov, A. (2019a). Synchronous scientific mobility and international collaboration: Case of russia. Processings of the 17th International Conference on Scientometrics \& Infometrics $1,1319-1328$.

Kosyakov, D., \& Guskov, A. (2019b). Impact of national science policy on academic migration and research productivity in Russia. Procedia Computer Science, 146, 60-71.

Latova, N., \& Savinkov, V. (2012). The influence of academic migration on the intellectual potential of Russia. European Journal of Education, 47, 64-76. 
Ledeneva, L. (2002). Professional migration intentions of Russian students abroad. Sotsiologicheskie Issledovaniya, 10, 94-101.

Leonard, D., \& Sensiper, S. (1998). The role of tacit knowledge in group innovation. California Management Review, 40, 112-132.

Lundvall, B. A. (1992). National Innovations Systems: Towards a Theory of Innovation and Interactive Learning (1st ed.). London: Pinter.

Markova, Y., Shmatko, N., \& Katchanov, Y. (2016). Synchronous International Scientific Mobility in the Space of Affiliations: Evidence from Russia, vol. 5.

Miguélez, E. (2013). Research networks and inventors' mobility as drivers of innovation: Evidence from Europe. Regional Studies 47, 1668-1685.

Miguélez, E., Moreno, R., \& Surinach, J. (2010). Inventors on the move: Tracing inventors' mobility and its spatial distribution. Papers in Regional Science 89, 251-274.

Mitin, D. (2011). Intellect migration: Origins, consequences and ways of solution. RUDN Journal of Political Science, 1, 41-47.

Naumova, T. (2014). Academic emigration from Russia. Russian Politics \& Law, 43, 77-91.

Paci, R., \& Usai, S. (2009). Knowledge flows across European regions. The Annals of Regional Science, 43, 669-690.

Perret, J. (2013). Knowledge as a Driver of Regional Growth (1st ed.). Heidelberg: Springer.

Perret, J. (2014). Comments on the impact of knowledge on economic growth across the regions of the Russian Federation. International Journal of Russian Studies, 3, 148-159.

Perret, J. (2015). Knowledge spillovers via patent citations across the regions of the Russian Federationevidence from European patent data. International Journal of Innovation and Regional Development, 6, 376-408.

Perret, J. (2017). Re-evaluating the knowledge production function for the regions of the Russian Federation. Journal of the Knowledge Economy.

Petrachenko, S. (2007). The problem of 'brain drain' from Russia in the context of intellectual security of the country. Vlast, 9, 52-55.

Piskunov, D., \& Lenshin, V. (1992). The choice facing Russian science: Partnership or brain drain. Mobility and Human Resource, 2, 123-133.

Ploder, M., Hartmann, C., Veres, E., \& Bertram, B. (2010). Sectoral Innovation Performance in the Automotive Sector. Europe Innova.

Rosstat (2012). Regions of Russia 2012 / regiony rossii. http://www.gks.ru

Scherngell, T. (2007). Interregionale Wissensspillovers in der Europaischen High-Tech Industrie - Eine Empirische Analyse, (1st ed.) Deutscher Universitats-Verlag.

Surinov, A. (1999). Questions of a quanititative measurement of regional price indices / Voprosy kolichestvennoj otsenki mezhregionalnykh indeksov tsen. Economic Journal of the VSHE / Ekonomicheskij Zhurnal VSHE, 4, 604-613.

Ter Wal, A. (2014). The dynamics of the inventor network in German biotechnology: Geographic proximity versus triadic closure. Journal of Economic Geography, 14, 589-620.

Verspagen, B., \& Schoenmakers, W. (2004). The spatial dimension of patenting by multinational firms in Europe. Journal of Economic Geography, 4, 23-42.

Welfens, P. J. J., Emons, O., \& Schroder, C. (2011). Regionale Innovations- und Spezialisierungsdynamik im Gesundheitssektor: Vergleichsperspektiven und wirtschaftspolitische Konsequenzen, (1st. ed.) Lucius and Lucius, Stuttgart.

Welfens, P. (2012). Regional innovation and cluster policies in the new and old economy. In P. Welfens, (Ed.), Clusters in Automotive and Information and Communication Technology, (1st ed., pp. 1-58) Springer, Heidelberg.

World Bank (2012). World development indicators database. http://www.worldbank.org

Publisher's Note Springer Nature remains neutral with regard to jurisdictional claims in published maps and institutional affiliations. 